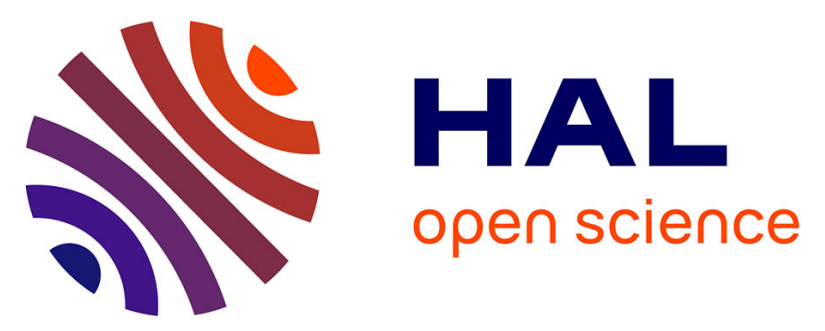

\title{
New MnII Complexes with an N/O Coordination Sphere from Tripodal N-Centered Ligands - Characterization from Solid State to Solution and Reaction with Superoxide in Non-Aqueous and Aqueous Media
}

Clotilde Policar, Stéphanie Durot, François Lambert, Michèle Cesario,

Florence Ramiandrasoa, Irène Morgenstern-Badarau

\section{To cite this version:}

Clotilde Policar, Stéphanie Durot, François Lambert, Michèle Cesario, Florence Ramiandrasoa, et al.. New MnII Complexes with an N/O Coordination Sphere from Tripodal N-Centered Ligands - Characterization from Solid State to Solution and Reaction with Superoxide in Non-Aqueous and Aqueous Media. European Journal of Inorganic Chemistry, 2001, 2001 (7), pp.1807-1818. hal-02011972

\author{
HAL Id: hal-02011972 \\ https://hal.science/hal-02011972
}

Submitted on 9 Apr 2020

HAL is a multi-disciplinary open access archive for the deposit and dissemination of scientific research documents, whether they are published or not. The documents may come from teaching and research institutions in France or abroad, or from public or private research centers.
L'archive ouverte pluridisciplinaire $\mathbf{H A L}$, est destinée au dépôt et à la diffusion de documents scientifiques de niveau recherche, publiés ou non, émanant des établissements d'enseignement et de recherche français ou étrangers, des laboratoires publics ou privés. 


\title{
New $\mathrm{Mn}^{\mathrm{II}}$ Complexes with an N/O Coordination Sphere from Tripodal $\mathrm{N}$-Centered Ligands - Characterization from Solid State to Solution and Reaction with Superoxide in Non-Aqueous and Aqueous Media
}

\author{
Clotilde Policar, ${ }^{*|a|}$ Stéphanie Durot, ${ }^{[a \mid}$ François Lambert, ${ }^{[a \mid}$ Michèle Cesario, ${ }^{[b]}$ \\ Florence Ramiandrasoa, ${ }^{\text {|al }}$ and Irène Morgenstern-Badarau ${ }^{\text {|a| }}$
}

Keywords: Carboxylate ligands / Bridging ligands / Tripodal ligands / Manganese / SOD mimics

The crystal structure of a dimeric bis( $\mu$-carboxylato $) \mathrm{Mn}^{\prime \prime} \mathrm{Mn}^{\|}$ complex (2) with a tetradentate $\mathrm{N}$-centered tripodal ligand, N,N-bis[(1-methylimidazol-2-yl)methyl]glycinate, is presented. The carboxylates are bridging monodentate. This complex shows some striking differences to the previously published parent compound $\mathbf{1}$ obtained with the closely related ligand $N$-[(1-methylimidazol-2-yl)methyl]-N-(2-pyridylmethyl)glycinate. The carboxylato bridges in both structures are shown to be disrupted in solution. The reactivities in solution of compounds $\mathbf{1}$ and $\mathbf{2}$ toward superoxide were studied. In anhydrous DMSO solutions, a pathway involving a bis( $\mu$-oxo $) \mathrm{Mn}^{\mathrm{III}} \mathrm{Mn}^{\mathrm{IV}}$ complex was identified. In water solutions, $I C_{50}$ values were measured by the Fridovich test $(1.7 \pm 0.2 \mu \mathrm{M}$ for 2 and $2.0 \pm 0.2 \mu \mathrm{M}$ for $\mathbf{1})$, which showed these complexes to be good superoxide scavengers. Association constants for the complexes were estimated by means of a method based on $I C_{50}$ measurements of the complexes under several conditions (alone and in the presence of excess ligand). They were found to be consistent with literature data.

\section{Introduction}

Superoxide $\left(\mathrm{O}_{2}^{-}\right)$is the product of single-electron reduction of dioxygen. It is the first species in the dioxygen reduction cascade en route to hydrogen peroxide $\left(\mathrm{H}_{2} \mathrm{O}_{2}\right)$ and the hydroxyl radical ( $\mathrm{HO}^{\circ}$ ), and is known to be involved in oxidative stress. ${ }^{[1-5]}$ Superoxide dismutases $(\mathrm{SODs})^{[6]}$ are metalloenzymes that actively protect cells against oxidative stress. They catalyze the dismutation of superoxide anion $\mathrm{O}_{2}^{-}$to hydrogen peroxide and oxygen. These enzymes can be classified into two major structural families, namely copper-zine SODs and manganese or iron SODs. ${ }^{[1,5,7-9]}$ SODs based on nickel have also been described, ${ }^{[10,111}$ but these have been much less well studied. Many complexes have been isolated and studied as superoxide scavengers. Such complexes contain either copper, ${ }^{[12-16]}$ iron, ${ }^{[17-25]}$ or manganese. ${ }^{|23,26-45|}$ In our laboratory, two families of ligands have been developed with a view to obtaining iron or manganese complexes that might possibly react with superoxide. One family has been based on heptadentate polyamine hindered ligands, ${ }^{[19,38]}$ while the other has been designed so as to reproduce the chemical environment of the active site in $\mathrm{Mn}$ and $\mathrm{Fe}$ SODs. In these enzymes, the first coordination sphere is a common feature, with an $\mathrm{N}_{3} \mathrm{O}_{1}$ set of ligand donors made up of three histidines and one monodentate carboxylate group, one histidine being more dis-

(a) Laboratoire de Chimie Bio-organique et Bio-inorganique, FRE 2127, Bâtiment 420. Universite Paris XI,

91405 Orsay Cedex, France

Fax: (internat.) + 33-1/69157231

E-mail: cpolicar@icmo,u-psud.fr

(D) Laboratoire de Cristallochimie, Institut de Chimie des Substances Naturelles du CNRS,

91198 Gif-sur-Yvette, France tant than the other ligands. ${ }^{[46-50]}$ Nitrogen-centered tripodal tetradentate ligands have been synthesized with three appended moieties [two aromatic amines (pyridine or $\mathrm{N}$ methylimidazole) and one carboxylate group], chosen in order to mimic the three closer ligands. Iron complexes have already been reported. ${ }^{[21,22]}$ Manganese complexes are now being studied. Compound $\mathbf{1}$, involving manganese(II) and $N$-[( I-methylimidazol-2-yl)methyl]- $N$-(2-pyridylmethyl)glycinate, hereafter referred to as IPG [acronym for (imidazolyl)(pyridyl)glycinate], has been described previously, It was shown to crystallize from $\mathrm{MeOH}$ with an infinite helical polymeric structure. ${ }^{[51]}$ We describe herein the crystal structure of compound $\mathbf{2}$, obtained from the closely related ligand $N, N$-bis[(1-methylimidazol-2-yl)methyl]glycinate [BIG; acronym for bis(imidazolyl)glycinate] and manganese(II). It crystallizes from water as a dinuclear bis( $\mu$-carboxylato)$\mathrm{Mn}^{11} \mathrm{Mn}^{11}$ complex. The reactivities in solution (anhydrous DMSO and aqueous buffer) of compounds $\mathbf{1}$ and $\mathbf{2}$ toward superoxide have been investigated and the results are reported herein.

\section{Results}

\section{Synthesis of the Ligands}

A given $N$-centered dissymmetric tripod can be synthesized by several pathways, depending on the order in which the different moieties are introduced. The yield-limiting step is usually the tertiarization of the amine. When this step is performed by reductive amination, improved yields over other synthetic methods are achieved, as previously reported in the case of $N-[(1-$ methylimidazol-2-yl)methyl]- $N$ - 
(2-pyridylmethyl)glycinate (IPG) ${ }^{[51]}$ We report here a highyielding, one-step synthesis of the ligand $N, N$-bis[(1-methylimidazol-2-yl)methyl]glycinate (BIG). A three-step synthesis of BIG has been published previously, which involved the preparation of N,N-bis[(1-methylimidazol-2-yl)methyl]amine from $\mathrm{N}$-methyl-2-carboxyimidazole and further $\mathrm{N}$-alkylation by treatment of the secondary amine with ethyl bromoacetate. ${ }^{[21]}$ The overall yield for the aldehyde to ester conversion by this new pathway was improved from $10 \%$ to $75 \%$ using a one-step reductive amination with $\mathrm{NaBH}_{3} \mathrm{CN}$ (see Scheme 1).<smiles>[X]c1ccn(C)c1CN(CC(=O)OC(F)(F)F)Cc1ccccn1</smiles><smiles>Cn1ccnc1CN(CC(=O)O[Na])Cc1nccn1C</smiles><smiles>CC#Cc1cnc(CN(CC(=O)OCC)Cc2nccn2C)n1C</smiles>

Scheme 1. Ligands IPG and BIG and the synthetic pathway leading to $\mathrm{BIG}$ : (i) EtOOCC $\mathrm{H}_{2} \mathrm{NH}_{3} \mathrm{Cl}, \mathrm{NaBH}_{3} \mathrm{CN}$, anhydrous $\mathrm{MeOH}$; (ii) $\mathrm{H}_{2} \mathrm{O} / \mathrm{EtOH}, \mathrm{K}_{2} \mathrm{CO}_{3}$, room temp., $48 \mathrm{~h}$

\section{Preparation of the Complexes}

$\mathrm{Mn}^{11}$ complexes were obtained from these two ligands with $\mathrm{PF}_{6}{ }^{-}$as the counteranion, either in anhydrous methanol or in water. With BIG, crystals were successfully grown from aqueous solution providing the dimeric compound $\mathbf{2}$. Experimental details are given in the Exp. Sect. (see also Table 1). With IPG, as previously described, crystals suitable for X-ray analysis were slowly grown from anhydrous methanolic solution (compound 1 ), providing a polymeric inorganic helix. ${ }^{[5]]}$

\section{Solid-State Characterization of Complex 2 - Comparison with Complex 1}

The X-ray structure of compound $\mathbf{1}$ has been described previously. It was shown to form infinite polymeric helices in the solid state, linked through carboxylato bridges in a rather unusual syn-anti geometry (see Figure 1). The $\mathrm{Mn}^{11}$ ion is hexacoordinated. Although the two tetradentate ligands IPG and BIG are very similar (see Scheme 1), the structure of compound $\mathbf{2}$ shows drastic differences from that of compound $\mathbf{1}$. The structure of complex 2 revealed the formation of a dinuclear complex, in which the two $\mathrm{Mn}^{\mathrm{II}}$ centers are linked by two oxygen atoms of the double carboxylate monodentate bridge $\left(\mu-\eta^{1}\right.$-carboxylato $)$ through a diamond-shaped core. In the crystal structure, the charge of the $\left[(\mathrm{BIG}) \mathrm{Mn}^{11}(\mu-\mathrm{OCO})_{2} \mathrm{Mn}^{11}(\mathrm{BIG})\right]^{2+}$ cation is balanced by the presence of two $\mathrm{PF}_{6}{ }^{-}$anions. Selected distances and angles are presented in Table 2 and a perspective view of the structure is shown in Figure 2.

A notable structural feature of the dinuclear $\mathrm{Mn}^{\mathrm{II}} \mathrm{com}$ plex is the heptacoordination of the manganese atom. The coordination environment of the metal ion consists of the
Table 1. Summary of crystal data, intensity measurements, and structure refinement for $\mathbf{2}$

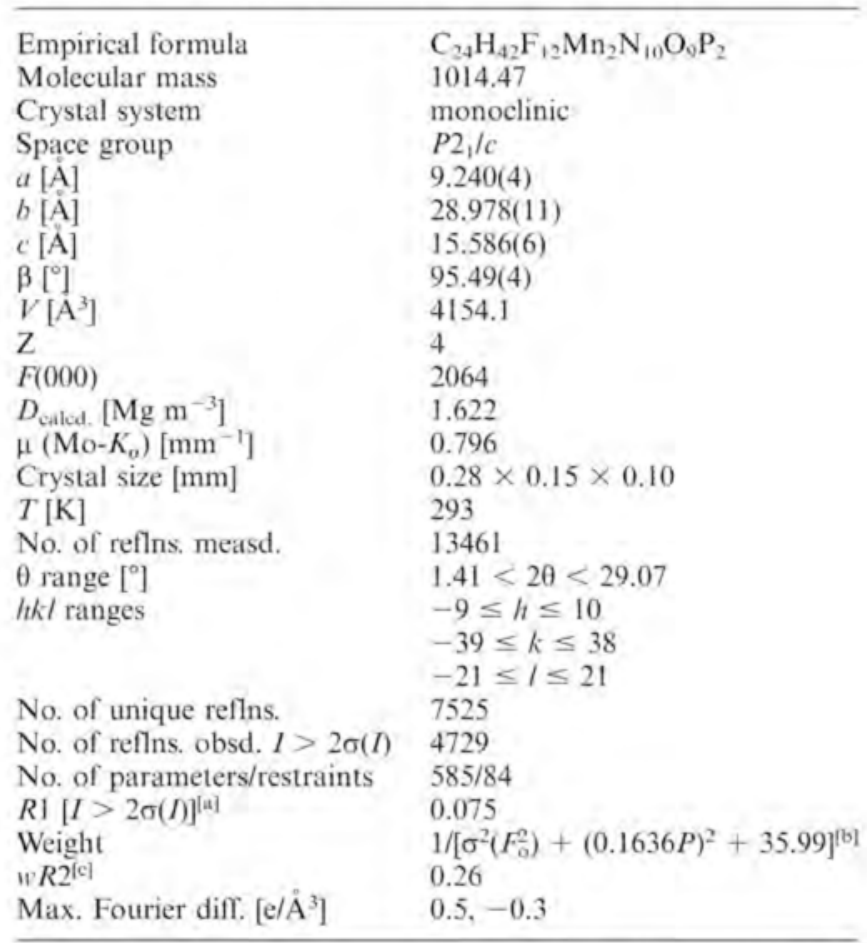

[a| $R 1=\Sigma|| F_{\mathrm{o}}|-| F_{\mathrm{c}} \| / \Sigma\left|F_{\mathrm{o}}\right| .-[\mathrm{b}] P=\left(F_{\mathrm{o}}^{2}+2 F_{\mathrm{c}}^{2}\right) / 3 .-[\mathrm{c} \mid w R 2=$ $\left\{\Sigma\left[w\left(F_{0}^{2}-F_{c}^{2}\right)^{2} / \Sigma\left[w\left(F_{o}^{2}\right)^{2}\right]\right\} 1 / 2\right.$.

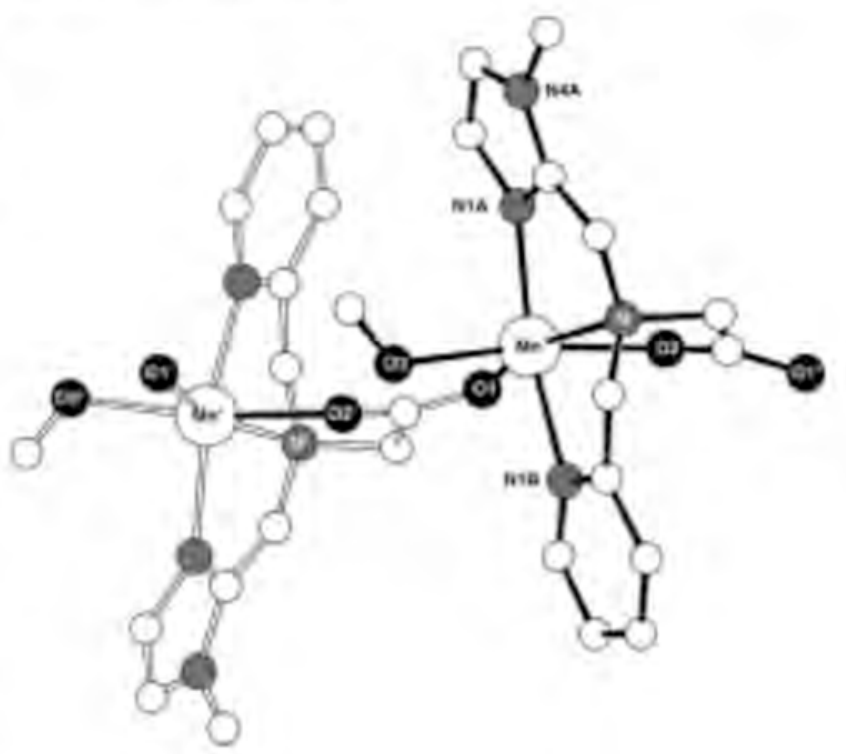

Figure 1. The polymeric association of the cationic chain of compound 1 with two adjacent monomeric units; hydrogen atoms have been omitted for clarity

three nitrogen donors N1A, N1B, N provided by the two imidazole rings and the tripodal $\mathrm{N}$ atom, and the oxygen atoms $(\mathrm{O} 1, \mathrm{O} 2)$ of the carboxylate groups grafted onto the tripodal $\mathrm{N}$ ligand, which bridge the two metal centers. The sixth and seventh coordination sites of each metal ion are occupied by two water molecules (Figure 2). In the IR spectrum, the presence of coordinated water was confirmed by 
Table 2. Selected bond lengths $[\dot{\mathrm{A}}]$ and angles $\left[{ }^{\circ}\right.$ ] for $\mathbf{2}$ [the corresponding values for $\mathbf{1}$ are given in brackets: data from ref. ${ }^{\mid 51}$ ]: a) for $\mathbf{1}$, $\mathrm{N} 1 \mathrm{~A}$ refers to the imidazole $\mathrm{N}$ and $\mathrm{N} 1 \mathrm{~B}$ to the pyridine $\mathrm{N}$ : b) $\mathrm{O}(1)$ refers to the closest carboxylato oxygen atom and. in the case of both 1 and 2, it is a carboxylato group belonging to the ligand capped over $\mathrm{Mn}^{\prime}$

\begin{tabular}{|c|c|c|c|c|}
\hline$M n-N(1 A)$ & $2.235(8)$ & $M n^{\prime}-N\left(1 A^{\prime}\right)$ & $2.204(8)$ & {$[2.13(2)]$} \\
\hline $\mathrm{Mn}-\mathrm{W}(2)$ & $2.228(7)$ & $M n^{\prime}-W\left(2^{\prime}\right)$ & $2.436(6)$ & \\
\hline$M n-N(1 B)$ & $2.244(8)$ & $M n^{\prime}-N\left(1 B^{\prime}\right)$ & $2.253(9)$ & {$[2.23(2)]$} \\
\hline $\mathrm{Mn}-\mathrm{O}(\mathrm{I})$ & $2.250(5)$ & $\mathrm{Mn}^{\prime}-\mathrm{O}(\mathrm{l})$ & $2.278(6)$ & {$[2.13(2)]$} \\
\hline $\mathrm{Mn}-\mathrm{O}(2)$ & $2.213(6)$ & $\mathrm{Mn}^{\prime}-\mathrm{O}(2)$ & $2.272(5)$ & {$[2.18(2)]$} \\
\hline$M n-W(1)$ & $2.360(7)$ & $M n^{\prime}-W\left(I^{\prime}\right)$ & $2.285(7)$ & \\
\hline $\mathrm{Mn}-\mathrm{N}$ & $2.483(8)$ & $\mathrm{Mn}^{\prime}-\mathrm{N}^{\prime}$ & $2.519(7)$ & {$[2.36(2)]$} \\
\hline$N(1 A)-M n-W(2)$ & $84.8(3)$ & $N\left(1 A^{\prime}\right)-M n^{\prime}-W\left(1^{\prime}\right)$ & $84.4(3)$ & \\
\hline$N(1 A)-M n-N(1 B)$ & $107.7(3)$ & $N\left(1 A^{\prime}\right)-M n^{\prime}-N\left(1 B^{\prime}\right)$ & $108.0(3)$ & {$[147.5(6)]$} \\
\hline$W(2)-M n-N(1 B)$ & $89.8(3)$ & $W\left(1^{\prime}\right)-M n^{\prime}-N\left(1 B^{\prime}\right)$ & $94.4(3)$ & \\
\hline$N(1 A)-M n-O(I)$ & $115.0(3)$ & $\mathrm{N}\left(1 \mathrm{~A}^{\prime}\right)-\mathrm{Mn}^{\prime}-\mathrm{O}(2)$ & $113.8(3)$ & \\
\hline$W(2)-M n-O(1)$ & $150.2(2)$ & $\mathrm{W}\left(\mathrm{I}^{\prime}\right)-\mathrm{Mn}^{\prime}-\mathrm{O}(2)$ & $148.8(2)$ & \\
\hline$N(1 B)-M n-O(1)$ & $103.7(3)$ & $\mathrm{N}\left(1 \mathrm{~B}^{\prime}\right)-\mathrm{Mn}^{\prime}-\mathrm{O}(2)$ & $102.8(3)$ & \\
\hline $\mathrm{N}(1 \mathrm{~A})-\mathrm{Mn}-\mathrm{O}(2)$ & $162.6(3)$ & $N\left(1 A^{\prime}\right)-M n^{\prime}-O(1)$ & $160.3(3)$ & \\
\hline $\mathrm{W}(2)-\mathrm{Mn}-\mathrm{O}(2)$ & $82.8(2)$ & $\mathrm{W}\left(\mathrm{I}^{\prime}\right)-\mathrm{Mn}^{\prime}-\mathrm{O}(1)$ & $82.4(2)$ & \\
\hline $\mathrm{N}(1 \mathrm{~B})-\mathrm{Mn}-\mathrm{O}(2)$ & $84.5(3)$ & $\mathrm{N}\left(1 \mathrm{~B}^{\prime}\right)-\mathrm{Mn}^{\prime}-\mathrm{O}(1)$ & $87.6(3)$ & \\
\hline $\mathrm{O}(1)-\mathrm{Mn}-\mathrm{O}(2)$ & $72.5(2)$ & $\mathrm{O}(2)-M n^{\prime}-\mathrm{O}(1)$ & $72.7(2)$ & {$[88.3(6)]$} \\
\hline$N(1 A)-M n-W(I)$ & $82.5(3)$ & $\mathrm{N}\left(1 \mathrm{~A}^{\prime}\right)-\mathrm{Mn}^{\prime}-\mathrm{W}\left(2^{\prime}\right)$ & $79.8(2)$ & \\
\hline$W(2)-M n-W(1)$ & $84.2(2)$ & $\mathrm{W}\left(1^{\prime}\right)-M n^{\prime}-W\left(2^{\prime}\right)$ & $83.4(2)$ & \\
\hline$N(1 B)-M n-W(1)$ & $167.7(3)$ & $\mathrm{N}\left(1 \mathrm{~B}^{\prime}\right)-\mathrm{Mn}^{\prime}-\mathrm{W}\left(2^{\prime}\right)$ & $171.8(2)$ & \\
\hline $\mathrm{O}(1)-\mathrm{Mn}-\mathrm{W}(1)$ & $77.2(2)$ & $\mathrm{O}(2)-\mathrm{Mn} \mathrm{n}^{\prime}-\mathrm{W}\left(2^{\prime}\right)$ & $75.8(2)$ & \\
\hline $\mathrm{O}(2)-\mathrm{Mn}-\mathrm{W}(1)$ & $84.0(2)$ & $\mathrm{O}(1)-\mathrm{Mn}^{\prime}-\mathrm{W}\left(2^{\prime}\right)$ & $84.3(2)$ & \\
\hline$N(1 A)-M n-N$ & $70.5(3)$ & $N\left(1 A^{\prime}\right)-M n^{\prime}-N^{\prime}$ & $70.2(3)$ & {$[75.7(6)]$} \\
\hline$W(2)-M n-N$ & $140.7(2)$ & $W\left(L^{\prime}\right)-M n^{\prime}-N^{\prime}$ & $143.0(2)$ & \\
\hline$N(I B)-M n-N$ & $70.2(3)$ & $N\left(1 B^{\prime}\right)-M n^{\prime}-N^{\prime}$ & $69.7(3)$ & {$[74.0(6)]$} \\
\hline $\mathrm{O}(1)-\mathrm{Mn}-\mathrm{N}$ & $69.0(2)$ & $\mathrm{O}(2)-\mathrm{Mn}^{\prime}-\mathrm{N}^{\prime}$ & $68.1(2)$ & {$[162.4(6)]$} \\
\hline $\mathrm{O}(2)-\mathrm{Mn}-\mathrm{N}$ & $126.3(2)$ & $\mathrm{O}(1)-\mathrm{Mn}^{\prime}-\mathrm{N}^{\prime}$ & $127.9(2)$ & {$[75.5(6)]$} \\
\hline$W(I)-M n-N$ & $120.7(2)$ & $\mathrm{W}\left(2^{\prime}\right)-\mathrm{Mn}^{\prime}-\mathrm{N}^{\prime}$ & $116.5(2)$ & \\
\hline
\end{tabular}

the appearance of two narrow lines at 3656 and $3580 \mathrm{~cm}^{-1} \cdot{ }^{[52]}$ These lines were absent in the IR spectrum of compound 1 , in which the $\mathrm{Mn}^{\mathrm{I}}$ ions do not bear coordinated water molecules. Moreover, when compound $\mathbf{2}$ was recrystallized from $\mathrm{D}_{2} \mathrm{O}$, these two lines were shifted to give one composite band at $3650 \mathrm{~cm}^{-1}$. This further confirms the assignment to coordinated water. The $\mathrm{M}-\mathrm{N}_{\text {tripodal }}$ distance is of the same order as has previously been found for similar compounds consisting of tripodal amines and Mn" [38.51.53,54] This distance is shorter than the sum of the van der Waals radii $(2.82 \AA \mathrm{A})$, indicating that the manganese ion is linked to the $\mathrm{N}_{\text {tripodal }}$ atom.

The bis[Mn( $\mu-\mathrm{OCO})]$ core is characterized by $\mathrm{Mn}-\mathrm{O}-\mathrm{Mn}$ angles of $108.4(2)^{\circ}$ and $106.4(4)^{\circ}$ and an $\mathrm{Mn}-\mathrm{Mn}$ distance of 3.672(2) A. This distance is of the same order of magnitude as those reported for the $\mathrm{Mn}^{\mathrm{II}}(\mu-$ $\mathrm{OCO})_{2} \mathrm{Mn}^{\mathrm{II}}$ core with a double monodentate bridging carboxylate group [3.712(2) and 3.726(4) A]. ${ }^{[54]}$ A relevant feature is the planarity of the diamond-shaped core, the four atoms $\mathrm{Mn}, \mathrm{O} 1, \mathrm{O} 2, \mathrm{Mn}^{\prime}$ being rigorously coplanar (mean displacement $0.001 \AA$ from the least-squares mean plane). A striking finding of the crystal structure determination of the dinuclear complex is a complex intra- and intermolecular hydrogen-bond network that connects the various hydrogen-bond acceptors $\left(\mathrm{COO}^{-}\right)$and the donors/acceptors (water molecules included in the cell).

The free oxygen atoms of the carboxylate groups, O9C and $\mathrm{O}^{9} \mathrm{C}^{\prime}$, and the water molecules $\mathrm{W1}$, W2 coordinated to the metal centers $\mathrm{Mn}$ and $\mathrm{Mn}^{\prime}$ are linked by strong intra- molecular hydrogen bonds (from $2.66 \AA$ to $2.74 \AA$ ). Another strong intramolecular hydrogen bond is evident between one water molecule W1 coordinated to the $\mathrm{Mn}$ ion and the other water molecule W2' linked to the second metal center $\mathrm{Mn}^{\prime}$. Small differences are observed for the bis( $\mu$-OCO) bridges. Oxygen atom O9C, which is not coordinated to the metal ion, is involved in only one intramolecular hydrogen bond, while the free oxygen atom $\mathrm{O}^{\prime} \mathrm{C}^{\prime}$ of the second carboxylate bridge is intra- and intermolecularly hydrogen-bonded in a twofold network.

Two- or threefold connected arrangements of the four water molecules coordinated to the metal centers and the water molecule W, cocrystallized, are seen in the crystal structure. The main features of the three-dimensional hydrogen-bond scheme are reported in Table 3.

\section{Studies in Solution: Reactivity of the Complexes Toward Superoxide}

Reactivity was studied in both anhydrous media and aqueous buffer. The studies in anhydrous media were motivated by the fact that the two complexes $\mathbf{1}$ and $\mathbf{2}$ display different levels of hydration. Direct reaction of the complexes with superoxide could be monitored in anhydrous media. DMSO was chosen as it solubilizes $\mathrm{KO}_{2}$ up to a relatively high concentration in comparison to other solvents (see Exp. Sect. for details). ${ }^{[55,56]}$ In aqueous buffer, an indirect test (namely the Fridovich test) was used. In order to investigate the reactions of $\mathrm{O}_{2}^{-}$with complexes $\mathbf{1}$ and $\mathbf{2}$ 


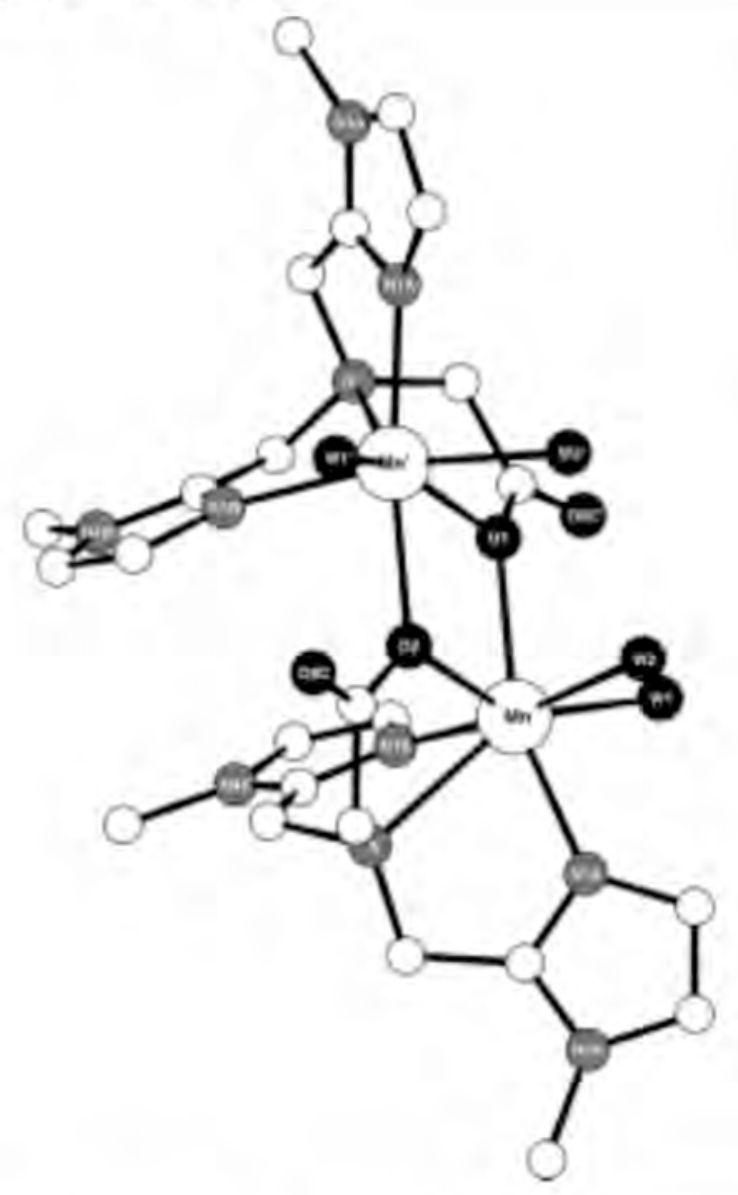

Figure 2. The molecular structure of the cation of complex 2: hydrogen atoms have been omitted for clarity

Table 3. Details of hydrogen-bonding features related to the $\mathrm{Mn}^{\text {II }}$ dinuclear complex $2\left(\hat{A},{ }^{\circ}\right)$

Intramolecular hydrogen bonds

\begin{tabular}{|c|c|c|c|}
\hline $\mathrm{O} 9 \mathrm{C}^{\prime} \cdots \mathrm{WI} \mathrm{I}^{\prime}$ & $2.665(9)$ & $\mathrm{C} 8 \mathrm{C}-\mathrm{O} 9 \mathrm{C}-\mathrm{W} 1^{\prime}$ & $103.1(6)$ \\
\hline $\mathrm{O} 9 \mathrm{C}^{\prime} \cdots \mathrm{W} 2$ & $2.698(9)$ & $\mathrm{C} 8 \mathrm{C}^{\prime}-\mathrm{O} 9 \mathrm{C}^{\prime}-\mathrm{W} 2$ & $102.7(6)$ \\
\hline $\mathrm{W} 1 \cdots \mathrm{W} 2^{\prime}$ & $2.736(8)$ & $\begin{array}{l}M n-W 1-W 2^{\prime} \\
M n^{\prime}-W 2^{\prime}-W_{1}\end{array}$ & $\begin{array}{l}101.5(3) \\
99.2(2)\end{array}$ \\
\hline
\end{tabular}

Intermolecular hydrogen bonds

$\begin{array}{llll}\mathrm{W} 1 \cdots \mathrm{W} 2^{\prime|a|} & 2.768(9) & \mathrm{Mn}-\mathrm{W} 1-\mathrm{W} 2^{\prime|b|} & 122.6(3) \\ \left.\mathrm{W} 1^{\prime} \cdots \mathrm{W}\right|^{|a|} & 2.889(9) & \mathrm{Mn}^{\prime}-\mathrm{W} 1^{\prime}-\mathrm{W} I^{[a]} & 104, \mathrm{I}(3) \\ \mathrm{W} 1^{\prime} \cdots \mathrm{W} & 2.742(13) & \mathrm{Mn}^{\prime}-\mathrm{W} 1^{\prime}-\mathrm{W} & 122.6(4) \\ \mathrm{W} 2^{\prime} \cdots \mathrm{O} 9 \mathrm{C}^{\prime[b]} & 2.716(9) & \mathrm{Mn}^{\prime}-\mathrm{W} 2^{\prime}-\mathrm{O} 9 \mathrm{C}^{\prime[b]} & 103.6(3)\end{array}$

(a) $=-x, 1-y, 2-z-\mid$ (b) $=1-x, 1-y, 2-z$.

in solution, their molecular properties in solution first needed to be characterized.

\section{Anhydrous DMSO Solutions}

Both complexes are soluble in DMSO. Mononuclear species are present in solution, as shown by EPR spectroscopy and mass spectrometry. The EPR spectra of 1 and 2 in DMSO $\left(10^{-4}\right.$ to $5 \times 10^{-3} \mathrm{~mol} \cdot \mathrm{dm}^{-3}$ based on $\mathrm{Mn}^{11}$ content) each show the sharp, six-line signal typical of mono- nuclear $\mathrm{Mn}^{\mathrm{II}}$ with an average separation of 102 Gauss (some smaller lines can be seen in between, which are known to be due to $\Delta m_{1}= \pm 1$ forbidden transitions) ${ }^{[57-59]}$ (see Figure $3 \mathrm{~A}$ ). Electrospray ionization mass spectrometry (ES) showed a peak at $m / z=392$ for $\mathbf{1}$ and at $m / z=395$ for 2 . These peaks correspond to $[(\mathrm{L}) \mathrm{Mn}+\mathrm{DMSO}]$ ( $\mathrm{L}$ being either IPG or BIG). For the sake of simplicity, the soluble species are referred to hereafter as MnIPG for $\mathbf{1}$ and as $\mathrm{MnBlG}$ for $\mathbf{2}$ and concentrations are given in terms of the Mn ${ }^{\text {II }}$ content.
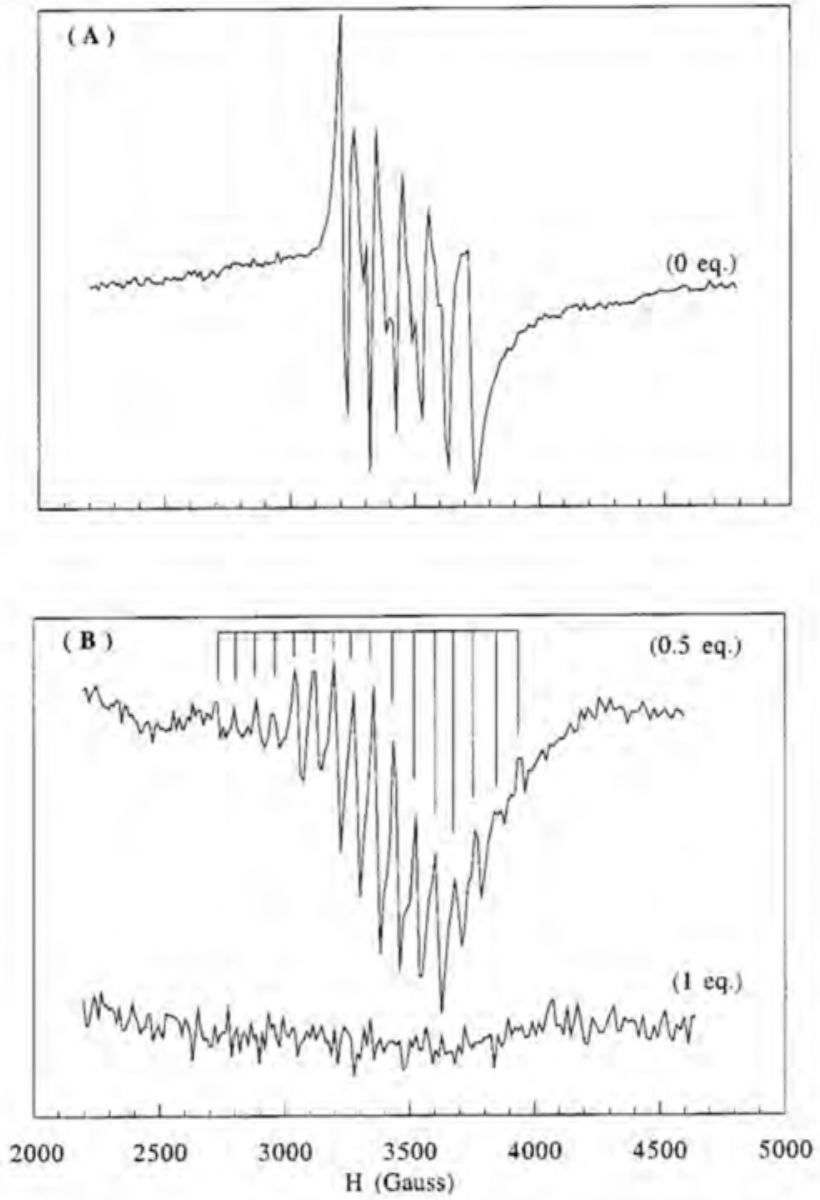

Figure 3. EPR spectra for the reaction of MnIPG $\left(6.5 \times 10^{-4} \mathrm{M}\right.$ based on $\mathrm{Mn}^{11}$ content) with potassium superoxide: $\mathrm{A}: 0$ equiv. of $\mathrm{O}_{2}^{-} ; \mathrm{B}: 0.5$ equiv. and 1 equiv, of $\mathrm{O}_{2}^{-}[T=8 \mathrm{~K}$, attenuation $44 \mathrm{~dB}$ (A) or $15 \mathrm{~dB}(\mathrm{~B})$, modulation $5 \mathrm{G}$, gain $3.2 \times 10^{5}, t_{\mathrm{c}}=100 \mathrm{~ms}$, sweep time $200 \mathrm{~s}]$

The cyclic voltammograms of both MnIPG and MnBIG in deoxygenated DMSO showed no reversible wave in the electroinactivity window of the solvent $(-2.25$ to $0.95 \mathrm{~V}$ vs. SCE), neither on platinum nor on glassy carbon working electrodes. Similarly, in acetonitrile, no wave was recorded in the range -1.8 to $1.8 \mathrm{~V}$ vs. SCE. Such behavior is not uncommon for $\mathrm{Mn}^{11}$ complexes. ${ }^{[38,60]}$

When the cyclic voltammogram of MnIPG or MnBIG in DMSO was recorded without deoxygenation, an irreversible cathodic wave was observed, corresponding to the reduction of dioxygen to superoxide. It is known that, in anhydrous DMSO, the redox couple $\mathrm{O}_{2} / \mathrm{O}_{2}^{-}$displays a revers- 
ible wave at $E_{1 / 2}=-0.73 \mathrm{~V}$ vs. SCE. [18,24,55,60,61] We verified that under our experimental conditions, in the absence of any complex, this reversible wave was indeed observed. Its reversibility confirmed the anhydrous nature of the solvent under the experimental conditions. The fact that the $\mathrm{O}_{2} /$ $\mathrm{O}_{2}^{-}$wave became irreversible in the presence of the complexes gave a first indication that the complexes do indeed react with superoxide.

When the DMSO solution was saturated with oxygen, another reduction peak appeared at a more positive potential $(+400 \mathrm{mV})$ than the $\mathrm{O}_{2} / \mathrm{O}_{2}^{-}$cathodic peak. Some similar pre-peaks have previously been reported for $\mathrm{Mn}^{\mathrm{I}}$ complexes, ${ }^{[38.60]}$ which were attributed to the reduction of dioxygen weakly bound to the metal center. ${ }^{[60]}$

\section{Reactivity of MnIPG and MnBIG Towards Superoxide in Anhydrous DMSO}

Incremental amounts of superoxide were added to an anhydrous DMSO solution containing either MnIPG or $\mathrm{MnBIG}\left(10^{-4}\right.$ to $5 \times 10^{-3} \mathrm{~mol} \cdot \mathrm{dm}^{-3}$ based on $\mathrm{Mn}^{11}$ content) and the course of the reaction at room temperature was monitored by UV/Vis spectrophotometry (room temp.), EPR (X-band) spectroscopy ( $100 \mathrm{~K}$ or $8 \mathrm{~K}$ ), and cyclic voltammetry (room temp.). In all these experiments, special care was taken to maintain the anhydrous character of the DMSO solutions. Saturated solutions of $\mathrm{KO}_{2}$ in DMSO were obtained as described in the Exp. Sect. Equivalents of superoxide added are given per manganese ion.

(a) Treatment of MnIPG with superoxide produced, after the addition of 1 equiv., a light-brown solution giving a typical UV/Vis spectrum as shown in Figure 4, featuring bands at 300,360 , and $510 \mathrm{~nm}$. EPR spectra were recorded at $100 \mathrm{~K}$ and $8 \mathrm{~K}$. The $\mathrm{Mn}^{11}$ signal intensity decreased on going from 0 to 0.5 equiv. of $\mathrm{O}_{2}^{-}$. At 0.5 equiv., a small multi-line signal was observed, which appeared more clearly at $8 \mathrm{~K}$ (Figure $3 \mathrm{~B}$ ). On going from 0.5 to 1 equiv., this multi-line signal decreased and was no longer observed beyond 1 equiv. Above 1.5 equiv., a signal due to superoxide was recovered. The superoxide content was estimated to be approximately 0.5 equiv. and 0.9 equiv. when 1.5 equiv. and 2 equiv., respectively, of superoxide had been added (see Exp. Sect.).

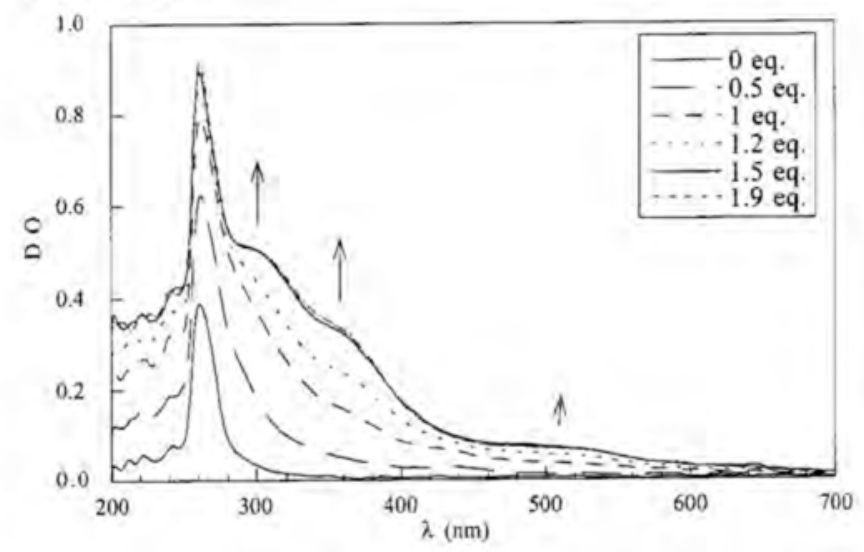

Figure 4. UV/Vis spectra for the reaction of MnIPG $\left(10^{-4} \mathrm{M}\right.$ based on $\mathrm{Mn}^{11}$ content) with potassium superoxide
The reactivity of MnIPG toward superoxide was also investigated by cyclic voltammetry. This was performed by studying the evolution of the $\mathrm{O}_{2} / \mathrm{O}_{2}^{-}$wave.

In anhydrous DMSO, the redox couple $\mathrm{O}_{2} / \mathrm{O}_{2}^{-}$shows a reversible wave at $E_{1 / 2}=-0.73 \mathrm{~V}$ vs. SCE. [18.24,55.60,61] The same reversible wave was observed from a deoxygenated $0.1 \mathrm{M} \mathrm{Bu}_{4} \mathrm{NPF}_{6} / \mathrm{DMSO}$ solution ( $15 \mathrm{~min}$ argon bubbling) to which a solution of $\mathrm{KO}_{2}$ in the same electrolyte had been added (Figure 5). This wave remained stable upon further deoxygenation, indicating that it was due to superoxide and not to dioxygen that might have resulted from superoxide disproportionation. To ensure that superoxide was stable under the experimental conditions, successive amounts of superoxide in $0.1 \mathrm{M} \mathrm{Bu}_{4} \mathrm{NPF}_{6} / \mathrm{DMSO}$ (see Exp. Sect.) were added to a $0.1 \mathrm{M} \mathrm{Bu}_{4} \mathrm{NPF}_{6} / \mathrm{DMSO}$ solution in the electrochemical cell in the absence of any complex. The intensity of the anodic wave was seen to remain stable over 5-10 min and to vary linearly with the superoxide concentration.

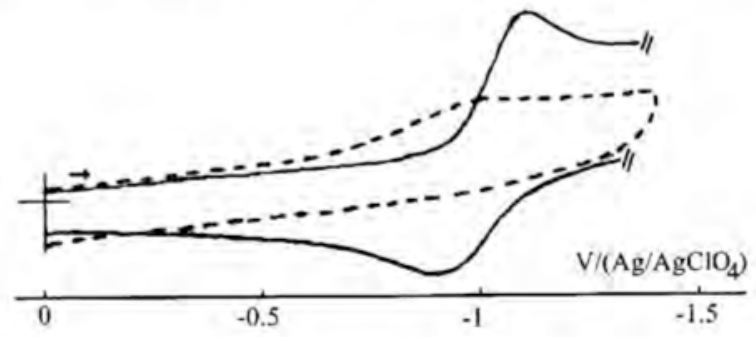

Figure 5. Cyclic voltammograms of a solution containing $\mathrm{O}_{2} / \mathrm{O}_{2}^{-}$; solid line: $5 \times 10^{-4} \mathrm{M} \mathrm{O}_{2}^{-}$: dashed line: $5 \times 10^{-4} \mathrm{M}$ MnIPG (based on $\mathrm{Mn}^{11}$ content $)+5 \times 10^{-4} \mathrm{M} \mathrm{O}_{2}^{-}$; potentials are reported $\mathrm{vs} . \mathrm{Ag} /$ $\mathrm{AgClO}_{4}$ in DMSO $(+0.252 \mathrm{~V}$ vs. SCE $)$

When the cyclic voltammogram of $\mathrm{MnIPG}$ was recorded without deoxygenation of the solution, the $\mathrm{O}_{2} / \mathrm{O}_{2}^{-}$reduction wave became irreversible, showing no re-oxidation of superoxide at the electrode, not even at $200 \mathrm{~m} \mathrm{~V} \cdot \mathrm{s}^{-1}$. Moreover, the $\mathrm{O}_{2} / \mathrm{O}_{2}^{-}$cathodic peak was slightly shifted to a more positive potential (see Figure 5), indicating an EC process. This shows that compound MnIPG reacts with superoxide produced at the electrode. When superoxide was added to the deoxygenated solution of MnIPG, no $\mathrm{O}_{2} / \mathrm{O}_{2}^{-}$wave was observed on going from 0.1 to 1 equiv. The superoxide wave appeared clearly after $2.5-3$ equiv. of superoxide had been added,

(b) MnBIG was found to display a similar behavior upon superoxide addition, but with a different stoichiometry. The brown color and the UV band at $300 \mathrm{~nm}$ appeared after addition of 2 equiv. of superoxide. The multi-line EPR signal appeared after the addition of 1.5 equiv. and an EPRsilent species was obtained after the addition of a further 0.5 equiv.

In cyclic voltammetry, the $\mathrm{O}_{2} / \mathrm{O}_{2}^{-}$wave was absent when superoxide was added to a deoxygenated solution of $\mathbf{2}$. After addition of 2 equiv. of superoxide, an irreversible cathodic wave appeared at $1.2 \mathrm{~V}$ vs. SCE, which intensified on adding further incremental amounts of superoxide. It was verified that the ligand $\mathrm{BIG}$ displays the same wave. 


\section{Reactivity of MnIPG and MnBIG Towards Superoxide in Aqueous Buffer}

The reactivity of our complexes towards superoxide was investigated in aqueous phosphate buffer $(\mathrm{pH}=7.8)$ by means of the xanthine/xanthine oxidase assay (hereafter referred to as the X/XO assay). This test, developed by Fridovich et al., is based on kinetic competition for superoxide reduction between the putative superoxide scavenger and ferricytochrome $c^{[?]}$ The reduction of ferricytochrome $c$ was monitored spectrophotometrically at $550 \mathrm{~nm}$. This test requires several preliminary checks in order to improve its reliability (see Exp. Sect.) ${ }^{[5,35,38.62]}$

Compounds 1 (MnIPG) and 2 (MnBIG) in potassium phosphate buffer at $\mathrm{pH}=7.8$ were found to inhibit the reduction of ferricytochrome $c$, as shown in Figure 6. Inhibition percentages were measured for several complex concentrations and $I C_{50}$ values were then deduced by two graphical methods (see Figure 7 and the Exp. Sect. for details). ${ }^{[7.35,63]}$ The effects of chelators such as bovine serum albumin (BSA) and ethylenediaminetetraacetate (EDTA) were investigated in order to gain some insight into the stabilities of the complexes. BSA has been reported to be a powerful biological chelating agent capable of suppressing the SOD-like activity of copper complexes. ${ }^{[5.14]}$ We have used it previously to test the activity of an (tris $\{2-[N-(2-$ pyridylmethyl)amino]ethyl $\}$ amine) $\mathrm{Mn}^{\text {II }}$ bis(hexafluorophosphate) (MnTPAA) in the X/XO assay. It was found that BSA $(5 \mathrm{mg} / \mathrm{mL})$ had no effect on the MnTPAA activity. ${ }^{[38]}$ Similarly, BSA $(5 \mathrm{mg} / \mathrm{mL})$ showed no effect on the MnIPG activity. A small effect was observed for MnBIG in

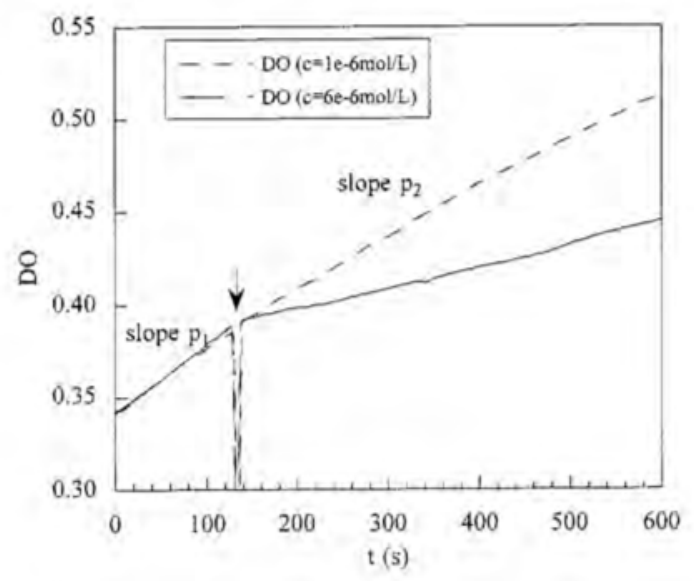

Figure 6. X/XO assay; $0-120 \mathrm{~s}$ : xanthine $(200 \mu \mathrm{M})$, ferricytochrome $c(22 \mu \mathrm{M})$, xanthine oxidase; after $120 \mathrm{~s}$ : xanthine $(200 \mu \mathrm{M})$, ferricytochrome $c(22 \mu \mathrm{M})$, xanthine oxidase, and compound MnBIG (concentration $c$, based on $\mathrm{Mn}^{\mathrm{N}}$ content); the arrow indicates the addition of compound MnBIG
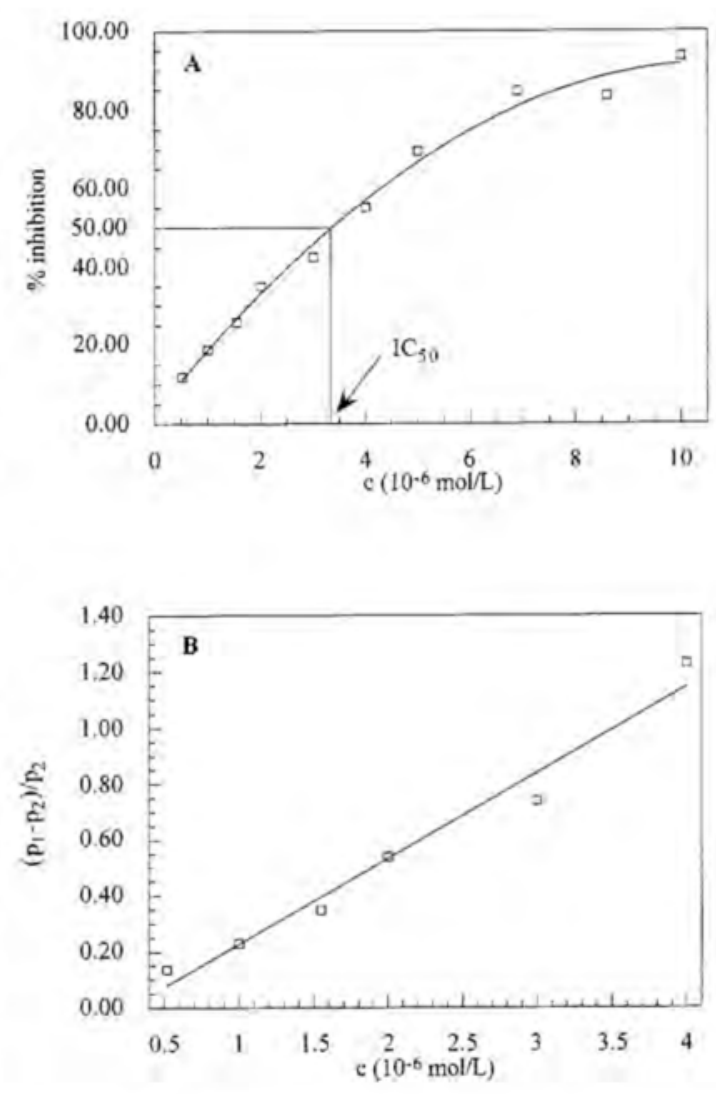

Figure 7. $I C_{50}$ determination in the case of compound MnIPG; A: $\%$ inhibition versus concentration; $\mathrm{B}:\left(p_{1}-p_{2}\right) / p_{2}$ versus concentration

that its $I C_{50}$ value was increased by a factor of 1.5 in the presence of BSA $(5 \mathrm{mg} / \mathrm{mL})$. The results suggest, at least for MnIPG, that as previously concluded for MnTPAA, ${ }^{[38]}$ activity might be retained in vivo.

To further investigate the stabilities of the complexes, activity was measured in the presence of an excess of EDTA ( $3 \mathrm{~mm}$, i.e. 1000 equiv.). The $I C_{50}$ values of $\mathrm{MnIPG}$ and $\mathrm{MnBIG}$ were found to be increased by factors of 20 and 25 . respectively (see Table 4), indicating low stabilities towards EDTA. Such contrasting behavior towards EDTA and BSA has previously been reported for (salen) $\mathrm{Mn}^{\mathrm{III}}$ complexes. It was interpreted in terms of EDTA binding Mn from the complex rather than merely reacting with free $\mathrm{Mn}$ released by the complex. ${ }^{[5]}$

These experiments indicate that some decoordination might occur at concentrations in the range of the $I C_{50}$. Ligands IPG and BIG were tested and were found to show no activity in the $\mathrm{X} / \mathrm{XO}$ assay. $I C_{50}$ values reported so far in this article are apparent $I C_{50}$ values $\left(I C_{50 \text { app }}\right)$ due to both

Table 4. Effect of chelators on the $I C_{s_{0}}$ value $[\mu \mathrm{M}]$

\begin{tabular}{lcccc}
\hline Compound & $I C_{50 \mathrm{app}}$ & $I C_{50}$ with EDTA $(3 \mathrm{~mm})$ & $I C_{50}$ with BSA & $I C_{50 \text { spe }}\left(I C_{50}\right.$ measured with excess ligand) \\
\hline MnBIG & $3.7 \pm 0.6$ & $90.0 \pm 0.7$ & $5.6 \pm 0.1$ & $1.7 \pm 0.2$ \\
MnIPG & $3.0 \pm 0.5$ & $62.3 \pm 0.7$ & $2.8 \pm 0.3$ & $2.0 \pm 0.2$ \\
\hline
\end{tabular}


Table 5. $I C_{50}$ values; comparison with literature data

\begin{tabular}{|c|c|c|c|}
\hline Compound & $I C_{50 \text { app }}$ & $I C_{30 \text { spe }}^{[a]}$ & Ref. \\
\hline $\mathrm{Mn}^{11}\left(\mathrm{ClO}_{4}\right)_{2}+$ EDTA $^{[\mathrm{b}]}$ & \multirow{2}{*}{\multicolumn{2}{|c|}{$\begin{array}{c}167 \pm 3 \\
140\end{array}$}} & this work \\
\hline $\mathrm{Fe}^{\mathrm{III} \mathrm{BIG}}$ & & & {$[92]$} \\
\hline $\mathrm{Mn}^{\text {"TTPAA }}{ }^{[\mathrm{e}]}$ & \multicolumn{2}{|c|}{50} & [38] \\
\hline $\mathrm{Mn}^{\prime \prime} \mathrm{DFB}^{[\mathrm{c}]}$ & \multicolumn{2}{|c|}{10.4} & [35] \\
\hline $\mathrm{Mn}^{\mathrm{II}}(\mathrm{PA})_{2}(\mathrm{PAH})\left(\mathrm{H}_{2} \mathrm{O}\right)^{[\mathrm{c}]}$ & \multicolumn{2}{|c|}{6.5} & [30] \\
\hline $\mathrm{Mn}^{11}\left(\mathrm{ClO}_{4}\right)_{2}$ & \multicolumn{2}{|c|}{$4.5 \pm 0.5$} & this work \\
\hline $\left.\mathrm{MnBIG}^{[\mathrm{d}]}\right]^{2}$ & $3.7 \pm 0.6^{[\mathrm{e}]}$ & $1.7 \pm 0.2^{[1]}$ & this work \\
\hline $\mathrm{MnIPG}^{[\mathrm{d}]}$ & $3.0 \pm 0.5[\mathrm{e}]$ & $2.0 \pm 0.2^{[1]}$ & this work \\
\hline $\mathrm{Mn}^{\mathrm{II}}(\mathrm{OBz})\left(3,5-i \mathrm{Pr}_{2} \mathrm{pzH}\right)\left[\mathrm{HB}\left(3,5-i \mathrm{Pr}_{2} \mathrm{pzH}\right)_{3}\right]$ & & & [33] \\
\hline $\mathrm{Mn}^{\prime \prime \prime}$ porphyrins & & & {$[23,43]$} \\
\hline MnSOD T. thermophilus & & & \\
\hline
\end{tabular}

${ }^{[* 1} / C_{50 \text { spe }}$ values were measured in the presence of excess ligand ( 15 equiv.). - ${ }^{[b]}$ This value was measured for a sample of $\mathrm{Mn}^{11}\left(\mathrm{ClO}_{4}\right)_{2}$ in the presence of excess EDTA (3 mM). - $\left.{ }^{\mathrm{k}}\right]$ TPAA: tris $\{2-[N-(2-$ pyridylmethyl)amino]ethyl $\}$ amine; DFB: desferrioxamine B; PA: picolinato; $\mathrm{HB}\left(3,5-i \mathrm{Pr}_{2} \mathrm{pzH}\right)_{3}$ hydrotris(3,5-diisopropyl-1-pyrazolyl)borate. - [d] $I C_{50}$ values are reported in terms of $\mathrm{Mn}$ concentration. - [c] This value is an average for three replicates performed for each of the two determination procedures. - if This value is an average for two replicates performed for each of the two determination procedures.

the complexes and free $\mathrm{Mn}^{\prime \prime}$. The $I C_{50}$ value for $\mathrm{Mn}\left(\mathrm{ClO}_{4}\right)_{2}$ $(4.5 \mu \mathrm{M})$ was found to be higher than those for the complexes under the same experimental conditions. Thus, $I C_{50 \text { app }}$ values represent an overestimation of the real $I C_{50}$ values (specific $I C_{50}$ ) that would have been measured without decoordination. To suppress this possible free $\mathrm{Mn}^{11}$ contribution to the inhibition, $I C_{50}$ values were measured in the presence of an excess of the ligand (15 equiv.), thereby providing specific $I C_{50}$ values $\left(I C_{50 \text { spe }}\right)$. These specific $I C_{50}$ values are reported in Table 4 and are compared with literature data in Table 5.

\section{Discussion}

The ligands IPG and BIG form two structurally distinct compounds with manganese(II). These two compounds reflect the rich structural diversity of (carboxylato)manganese complexes, as has been stressed by Iikura et al. ${ }^{[54]}$ The coordination sphere about the manganese(II) ions adopts various geometries (see Table 2, Figure 1 and 2) and has various coordination numbers ( 6 or 7 for these two examples). This structural variety stems from the carboxylato moiety, which is $\mu-\eta^{2}$-carboxylato-syn-anti in the polymeric helix adopted by $\mathbf{1}$ and $\mu-\eta \eta^{1}$-carboxylato in the dimeric structure of $\mathbf{2}$ in the solid state.

\section{Reactivity in Anhydrous DMSO}

Complexes $\mathbf{1}$ and $\mathbf{2}$ have different levels of hydration. In the reaction with superoxide, this hydration level is of critical importance as two protons are necessary for the superoxide reduction step producing $\mathrm{H}_{2} \mathrm{O}_{2}$. The ping-pong mechanism proposed for the enzyme suggests an innersphere electron-transfer, the first step being the binding of superoxide to the metal center. ${ }^{[99]}$ Two concomitant pathways (inner- and outer-sphere electron transfer) have also been proposed for macrocyclic $\mathrm{Mn}^{11}$ derivatives. ${ }^{[34,37,39.44]}$ With compound 1, which does not have any coordinated water molecules, it is possible to test the reactivity in anhydrous media and thus, in the case of an inner-sphere mechanism, we may expect to characterize an $\mathrm{Mn}$-superoxide adduct or a derivative thereof. This can be compared with the reactivity of complex $\mathbf{2}$, as the presence of water should lead to some effective reaction with superoxide.

MnIPG reacts with 1 equiv. of superoxide, producing an EPR-silent species. After addition of 0.5 equiv., a $g=2,16$ line signal is observed in the EPR spectrum (see Figure 3). This indicates that a dimeric $\mathrm{Mn}-\mathrm{Mn} S=1 / 2$ ground-state compound is obtained. This signal displays a width of 1200 $\mathrm{G}$ and an average spacing of $75 \mathrm{G}$. Such a spectrum is typical of bis( $\mu$-oxo $) \mathrm{Mn}^{\mathrm{III}} \mathrm{Mn}^{\mathrm{IV}}$ complexes. ${ }^{[61,64-75]}$ The conversion of $\mathrm{Mn}^{\text {"I }}$ to bis( $\mu$-oxo $) \mathrm{Mn}^{\text {III }} \mathrm{Mn}^{1 \mathrm{~V}}$ species has been estimated to be $70 \%$ based on a comparison with the spectrum of a fully characterized $\mathrm{Mn}^{11 \mathrm{II}} \mathrm{Mn}^{\mathrm{IV}}$ compound. ${ }^{[7]}$ The $\mathrm{Mn}^{\mathrm{III}} \mathrm{Mn}^{\mathrm{IV}}$ species further reacts with 0.5 equiv: of superoxide leading to an EPR-silent species, which could be either an $\mathrm{Mn}^{1 \mathrm{II}} \mathrm{Mn}^{\mathrm{III}}$ or an $\mathrm{Mn}^{\mathrm{IV}} \mathrm{Mn}^{\text {IV }}$ species. This is consistent with the UV/Vis spectrum, as a possible assignment for the 300 and $360 \mathrm{~nm}$ bands is an $\mathrm{O} \rightarrow \mathrm{Mn}^{\text {IV }}$ LMCT. ${ }^{[74,77.78]}$ Scheme 2 provides a rationalization of these experimental observations.

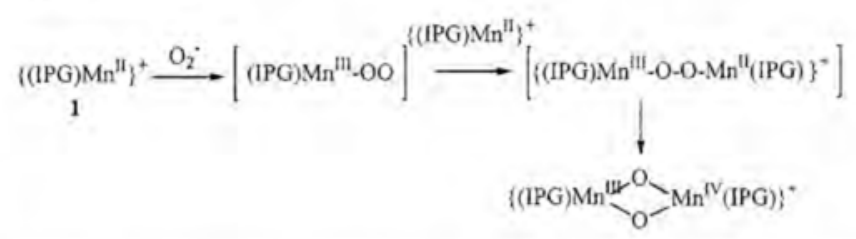

Scheme 2, Possible mechanism for bis $(\mu-o x o) \mathrm{Mn}^{\mathrm{II}} \mathrm{Mn}^{\mathrm{IV}}$ dimer formation (after reaction of potassium superoxide with MnIPG)

The fact that the superoxide signal is recovered upon addition of 1.5 equiv. of superoxide shows that the silent EPR species formed at 1 equiv. of superoxide do not react with superoxide, at least in anhydrous media. A similar mechanism has previously been proposed for manganese- 
porphyrins ${ }^{[6]]} \mathrm{A}$ ( $\mu$-peroxo) $\mathrm{Mn}^{\text {"I }} \mathrm{Mn}^{\text {III }}$ species could also produce a $g=2$, multi-line signal if the ground state had $S=1 / 2$. However, as has been pointed out in the literature, a much larger spectrum would be expected. ${ }^{[65]}$ Moreover, such a ( $\mu$-peroxo) $\mathrm{Mn}^{\mathrm{II}} \mathrm{Mn}^{\mathrm{II}}$ species would be expected to be unstable, whereas we found the multi-line signal to persist after the EPR tube had been left at room temperature for $5 \mathrm{~min}$.

MnBIG exhibited the same pattern of spectroscopic and voltammetric characteristics, but only after 1 equiv. of superoxide per manganese ion had already been consumed. This observation has to be related to its level of hydration. The presence of water allows the production of hydrogen peroxide, either by direct reaction with superoxide or by reaction with an $\mathrm{Mn}$-superoxide adduct. When the amount of superoxide was increased, an irreversible cathodic wave appeared at $1.2 \mathrm{~V}$ vs. SCE, which was shown to be due to the ligand BIG. This probably indicates destruction of the complex with release of the ligand.

\section{Reactivity in Aqueous Buffer}

The use of the $\mathrm{X} / \mathrm{XO}$ assay to determine catalytic SODlike activity is controversial. It has been shown, first by others, using stopped-flow techniques, ${ }^{[5][62]}$ and then by us, using pulsed radiolysis, ${ }^{[38]}$ that such an indirect test can give positive results both in the case of a catalytic scavenger and in the case of a stoichiometric superoxide scavenger. As a matter of fact, a small amount of superoxide is produced in the $\mathrm{X} / \mathrm{XO}$ assay. For compounds displaying high $I C_{50}$ values (in excess of $1 \mu \mathrm{M}$ ), the conditions required to probe catalytic behavior may not be fulfilled as $n_{\text {complex }}>>n_{\text {sup- }}$ eroxide in the experiment. However, this test remains relevant for several reasons. The $\mathrm{X} / \mathrm{XO}$ system provides a stationary state of superoxide of low concentration, which is closer to what is usually encountered in vivo. ${ }^{[14]}$ Moreover, it provides a simple means of investigating the reactivities of complexes towards superoxide in aqueous buffers and of assessing the effect of additional compounds (e.g., chelators). ${ }^{[14,15.23,42,43]}$

The $\mathrm{X} / \mathrm{XO}$ assay has proven that complexes $\mathbf{1}$ and $\mathbf{2}$ react with superoxide in aqueous solution. Experiments performed in the presence of excess chelators (BSA, EDTA) have shown that the complexes are partially decoordinated in the $I C_{50}$ concentration range. Specific $I C_{50}\left(I C_{50 \text { spe }}\right)$ values were thus measured using an excess of the ligand. $\mathrm{MnBIG}$ and MnIPG show very close specific $I C_{50}$ values, which is consistent with the two ligands being closely related. Their $I C_{50 \text { spe }}$ values fall at the low end of the range of those reported in the literature for $\mathrm{Mn}^{\mathrm{II}}$ complexes (see Table 4). Much lower $I C_{50}$ values have been reported for

Table 6. Association constants with $\mathrm{Mn}^{\text {" }}$ estimated for BIG and IPG and comparison with literature data: constants are given for the equilibrium $\mathrm{Mn}^{\mathrm{II}} / \mathrm{L}(1: 1)$

\begin{tabular}{|c|c|c|c|}
\hline Ligand & Denticity & $\log K\left(T\left[{ }^{\circ} \mathrm{C}\right]\right.$ ionic strength $)$ & Ref. \\
\hline Pyridine & \multirow[t]{2}{*}{ monodentate } & $0.14(25 / 0.5)$ & {$[79]$} \\
\hline Acetic acid & & $0.8(25 / 0.16)$ & {$[80]$} \\
\hline 2-Aminomethyl-6-methylpyridine & \multirow[t]{11}{*}{ bidentate } & $1.95(25 / 0.1)$ & [81] \\
\hline D-Tartaric acid & & $2.49(25 / 0.1)$ & {$[80]$} \\
\hline L-2-Aminopropanoic acid (L-alanine) & & $2.5(25 / 0.1)$ & [81] \\
\hline Diglycolic acid & & $2.53(25 / 0.1)$ & {$[80\}$} \\
\hline 2,2'-Bipyridine & & $2.62(25 / 0.1)$ & [79] \\
\hline 2-(Aminomethyl)pyridine & & $2.66(20 / 0.1)$ & [79] \\
\hline Ethylenediamine & & $2.67(25 / 0.1)$ & {$[79]$} \\
\hline Phthalic acid & & $2.74(25 / 0)$ & {$[80\}$} \\
\hline Aminoacetic acid (glycine) & & $2.8(25 / 0.1)$ & [81] \\
\hline 4-(2-Aminoethyl)imidazole (histamine) & & $3.0(25 / 0.2)$ & [79] \\
\hline 1,10-Phenanthroline & & $4.0(25 / 0.1)$ & {$[79]$} \\
\hline Diethylenetriamine & \multirow[t]{3}{*}{ tridentate } & $3.99(30 / 0.1)$ & [79] \\
\hline Di(2-picolyl)amine (DPA) & & $4.16(25: 0.1)$ & [79] \\
\hline $2,2^{\prime}, 2^{\prime \prime}$-Terpyridine & & $4.4(25 / 0.002-0.1)$ & [ह1] \\
\hline Oxybis(propanedioic acid) & \multirow[t]{8}{*}{ tetradentate } & $4.51(25 / 0.1)$ & [80] \\
\hline Triethylenetetramine & & $4.9(25 / 0.1)$ & [79] \\
\hline BIG & & $5.3(25 / 0.13)$ & this work \\
\hline Tris(2-picolyl)amine (TPA) & & $5.6(20 / 0.1)$ & {$[79]$} \\
\hline Tris(2-aminoethyl)amine (TREN) & & $5.8(25 / 0.1)$ & [79] \\
\hline$N$-(2-Carboxyphenyl)iminodiacetic acid & & $5.85(25 / 0.1)$ & [81] \\
\hline$N, N^{\prime}$-Di(2-picolyl)ethylenediamine & & $5.9(25 / 0.1)$ & [79] \\
\hline IPG & & $6.0(25 / 0.13)$ & this work \\
\hline$N . N, N^{\prime}, N^{\prime}$-(2-Aminoethyl)ethylenediamine & \multirow[t]{2}{*}{ hexadentate } & $9.26(25 / 0.1)$ & {$[79]$} \\
\hline$N, N, N^{\prime}, N^{\prime}$-Tetrakis(2-picolyl)ethylenediamine (TPEN) & & $10.3(20 / 0.1)$ & [79] \\
\hline
\end{tabular}


$\mathrm{Mn}$-porphyrin compounds (see Table 4), but in these cases the manganese ion is in an $\mathrm{Mn}^{\mathrm{III}}$ oxidation state. The $I C_{50}$ value measured for MnBIG is more sensitive to the presence of chelators (EDTA, BSA, or BIG) (see Table 4). Qualitatively, this indicates that MnBIG has a smaller association constant $K_{\mathrm{BIG}}$ than MnIPG $\left(K_{\mathrm{IPG}}\right)$. Association constants could be roughly estimated from the apparent and specific $I C_{50}$ values. Apparent $I C_{50}$ values depend on the proportion of complex and $\mathrm{Mn}^{\mathrm{II}}$ in the solution, and hence on the association constant. The apparent $I C_{50}$ values could be approximated as the weighted average of the specific $I C_{50}$ values for both compounds and $\mathrm{Mn}^{11}: I C_{50 \text { app }}(n)=$ $I C_{50 \text { spe }}(n) \cdot(1-\alpha)+I C_{50 \text { spe }}\left(\mathrm{Mn}^{\mathrm{U}}\right) \cdot \alpha \quad(n=$ MnIPG or MnBIG), $\alpha$ being the dissociation coefficient. This led to $K_{\mathrm{IPG}}=10^{6.0}$ and $K_{\mathrm{BIG}}=10^{5.3}$, respectively. Literature data on association constants of $\mathrm{Mn}^{\prime \prime}$ complexes involving ligands of various denticity are reported in Table 5, together with our results from the present work. ${ }^{[79-81]}$ The $K_{\text {ass }}$ values estimated here for BIG and IPG are of the expected order of magnitude for tetradentate ligands and $\mathrm{Mn}^{\mathrm{H}}$.

As already mentioned, this $\mathrm{X} / \mathrm{XO}$ assay is unable to distinguish between a catalytic and a stoichiometric scavenger for compounds showing $I C_{50}$ values greater than $1 \mu \mathrm{m}$. Direct measurements of SOD activity using an excess of superoxide are necessary. ${ }^{[5]}$ Pulsed-radiolysis kinetic analysis is now underway.

\section{Conclusion}

The preparation of compound 2 from $\mathrm{Mn}^{11}$ and $N, N-$ bis[(1-methylimidazol-2-yl)methyl]glycinate (BIG) and its solid-state structure have been described. This compound has been shown to crystallize as an $\mathrm{Mn}^{11} \mathrm{Mn}^{11}$ dimer with a double carboxylato monodentate bridge $\left(\mu-\eta^{1}\right.$-carboxylato). Its geometry differs from that of compound $\mathbf{1}$, an $\mathrm{Mn}^{\mathrm{II}}$ compound prepared with the closely related ligand $N$-[(1-methylimidazol-2-yl)methyl]- $N$-(2-pyridylmethyl)glycinate, IPG, which was previously shown to crystallize as a helical polymer ${ }^{[5]]}$ Both these bridged structures are disrupted in DMSO, leading to monomeric species. In solution, compounds $\mathbf{1}$ and $\mathbf{2}$ have been shown to react with superoxide, both in anhydrous media and in aqueous buffer. They have been shown to form bis( $\mu$-oxo $)$ dimers in anhydrous media, such dimers being unreactive toward superoxide. $I C_{50}$ values obtained in solution for these two compounds are among the best reported for $\mathrm{Mn}^{\mathrm{II}}$ complexes, showing that the metal environment is appropriate for reaction with superoxide. However, the dimer formation, as seen under anhydrous conditions, might represent a pathway for inhibition of the activity toward superoxide in aqueous solution. We are currently working on modification of the ligand in order to prevent this possible dimerization and to enhance the stability of the complexes.

\section{Experimental Section}

General: IR spectra (KBr) were recorded with a Bruker IFS 66 FTIR spectrometer. - ${ }^{1} \mathrm{H}$ NMR spectra were recorded with Bruker
AM 200 and AM 250 spectrometers. - X-band electron paramagnetic resonance (EPR) spectra were recorded with a Bruker ER $200 \mathrm{E}$ spectrometer. - Cyclic voltammetry experiments were performed with an EG\&G Princeton Applied Research Model 362 potentiostat connected to an Ifelec IF 2502 xy recorder. - Electronic absorption spectra were recorded with a Safas 190 DES double-mode spectrophotometer. - Chemical reagents were purchased from either Aldrich or Acros and were used without further purification. Extra-dry DMSO was purchased from Acros. ${ }^{[82]}$ Xanthine oxidase and ferricytochrome $c$ were purchased from Sigma.

\section{Syntheses and Characterization}

[(Ethoxycarbonyl)methyl|bis|(1-methylimidazol-2-yl)methyl]amine: Under argon at $0^{\circ} \mathrm{C}$, sodium cyanoborohydride ( 5 mmol. $0.32 \mathrm{~g}$ ) was added to a deoxygenated solution of 1-methylimidazol-2-carboxaldehyde ${ }^{\mid 83]}(4.7 \mathrm{mmol}, 0.52 \mathrm{~g})$ and glycine ethyl ester hydrochloride $\left(\mathrm{ClNH}_{3} \mathrm{CH}_{2} \mathrm{COOEt}\right)(4.7 \mathrm{mmol}, 0.65 \mathrm{~g})$ in anhydrous $\mathrm{MeOH}(10 \mathrm{~mL})$. After $2 \mathrm{~h}$ at $0^{\circ} \mathrm{C}$, the mixture was stirred for $12 \mathrm{~h}$ at room temperature. The solution was then cooled to $0{ }^{\circ} \mathrm{C}$ and acidified to $\mathrm{pH}=5.5$ with $\mathrm{CF}_{3} \mathrm{COOH}$, whereupon 1-methylimidazol-2-carboxaldehyde ( $7 \mathrm{mmol}, 0.775 \mathrm{~g}$ ) (in anhydrous $\mathrm{MeOH}$. $2 \mathrm{~mL}$ ) and sodium cyanoborohydride ( $9 \mathrm{mmol}, 0.48 \mathrm{~g}$ ) were added. After $2 \mathrm{~h}$ at $0{ }^{\circ} \mathrm{C}$, the solution was stirred for $12 \mathrm{~h}$ at room temperature. It was then filtered, the methanol was evaporated, and the residual oil was extracted from the aqueous phase $(\mathrm{pH}=8)$ with $\mathrm{CH}_{2} \mathrm{Cl}_{2}$. The combined organic phases were dried with $\mathrm{Na}_{2} \mathrm{SO}_{4}$ and concentrated. A yellow oil was obtained, which was purified by column chromatography $\left(\mathrm{SiO}_{2} ; \mathrm{MeOH} / \mathrm{CH}_{2} \mathrm{Cl}_{2}, 1: 9\right)$. Yield $(1.1 \mathrm{~g}$, $75 \%) .{ }^{1} \mathrm{H} \mathrm{NMR}\left(\mathrm{CDCl}_{3}\right): \delta=1.17(\mathrm{t}, 3 \mathrm{H}, J=7.25 \mathrm{~Hz}$, $\mathrm{CH}_{3} \mathrm{CH}_{2} \mathrm{COO}$ ), 3.34 (s, $2 \mathrm{H}, \mathrm{NCH}_{2} \mathrm{COOEt}$ ), 3.52 (s, $6 \mathrm{H}, \mathrm{CH}_{3} \mathrm{~N}_{\mathrm{im}}$ ), $3.80\left(\mathrm{~s}, 4 \mathrm{H}, \mathrm{Im}-\mathrm{CH}_{2} \mathrm{~N}\right), 4.04$ (q, $2 \mathrm{H}, J=7.25 \mathrm{~Hz}, \mathrm{CH}_{3} \mathrm{CH}_{2} \mathrm{COO}$ ), 6.80 (d, $2 \mathrm{H}, J=2.25 \mathrm{~Hz}, \mathrm{H}_{\mathrm{im}}$ ), 6.84 (d, $2 \mathrm{H}, J=2.25 \mathrm{~Hz}, \mathrm{H}_{\mathrm{im}}$ ).

Potassium N,N-Bis|(1-methylimidazol-2-yl)methylglycinate (BIG): A solution of $N, N$-bis[(1-methylimidazol-2-yl)methyl]glycine ethyl ester $(0.5 \mathrm{~g})$ in ethanol $(12 \mathrm{~mL})$ was added to a solution of potassium carbonate $(0.52 \mathrm{~g})$ in water $(35 \mathrm{~mL})$. The resulting solution was stirred for $2 \mathrm{~d}$ at room temperature. The ethanol was then evaporated and the aqueous phase was washed with $\mathrm{CH}_{2} \mathrm{Cl}_{2}(2 \times$ $10 \mathrm{~mL}$ ). After concentration to dryness, residual $\mathrm{K}_{2} \mathrm{CO}_{3}$ was removed by extracting the carboxylate with anhydrous $\mathrm{MeOH}$. Yield: $95 \%$. - ${ }^{1} \mathrm{H}$ NMR $\left(\mathrm{D}_{2} \mathrm{O}\right): \delta=3.10$ (s, $\left.2 \mathrm{H}, \mathrm{NCH}_{2} \mathrm{COOK}\right), 3.45$ (s. $\left.6 \mathrm{H}, \mathrm{CH}_{3} \mathrm{~N}_{\mathrm{im}}\right), 3.80\left(\mathrm{~s}, 4 \mathrm{H}, \mathrm{Im}-\mathrm{CH}_{2} \mathrm{~N}\right), 6.86(\mathrm{~d}, 2 \mathrm{H}, J=2.25 \mathrm{~Hz}$, $\left.\mathrm{H}_{\mathrm{im}}\right), 6.89\left(\mathrm{~d}, 2 \mathrm{H}, J=2.25 \mathrm{~Hz}, \mathrm{H}_{\mathrm{im}}\right)$.

I $\mathrm{Mn}(\mathrm{BIG})\left(\mathrm{H}_{2} \mathrm{O}\right)_{2} \mathrm{l}_{2} \cdot \mathbf{P F F}_{6}$ (2): The $\mathrm{pH}$ value of a $2 \times 10^{-3} \mathrm{M}$ solution of $\mathrm{BIG}$ in water was adjusted to $8-8.5$ by the addition of $\mathrm{HCl}$. After evaporation of the water, the solid was dried overnight under reduced pressure in the presence of $\mathrm{P}_{2} \mathrm{O}_{5}$, and then $\mathrm{KCl}$ was removed by extraction of the ligand with anhydrous methanol. Typically, dimer crystals were obtained as follows: $\mathrm{MnBr}_{2}(0.52 \mathrm{mmol}$. $112 \mathrm{mg}$ ) in deoxygenated doubly distilled water $(15 \mathrm{~mL})$ was added to a solution of the ligand $(160 \mathrm{mg})$ in deoxygenated doubly distilled water $(10 \mathrm{~mL})$. The resulting mixture was allowed to stand for $2 \mathrm{~h}$ at $40{ }^{\circ} \mathrm{C}$. Then, after cooling, a deoxygenated solution of $\mathrm{NH}_{4} \mathrm{PF}_{6}$ (3 equiv., $260 \mathrm{mg}$ ) in doubly distilled water $(10 \mathrm{~mL}$ ) was added dropwise. The resulting solution was left to stand for 3 weeks, allowing crystals to grow (see crystal data below). For further characterization and experiments, these crystals were ground and dried in vacuo over $\mathrm{P}_{2} \mathrm{O}_{5}$ for $48 \mathrm{~h}$. Yield: $260 \mathrm{mg}(55 \%)$. $\left[\mathrm{C}_{12} \mathrm{H}_{16} \mathrm{~N}_{5} \mathrm{O}_{2} \mathrm{Mn}\left(\mathrm{H}_{2} \mathrm{O}\right)\right]_{2} \cdot 2 \mathrm{PF}_{6}:$ calcd. C $30.01, \mathrm{H} 3.78, \mathrm{~N} 14.58, \mathrm{~F}$ 23.74, P 6.45, Mn 11.44; found C 30.43, H 3.66, N 14.61, F 23.38, P 6.88, Mn 11.46. - IR ( $\mathrm{KBr}): \tilde{v}=3656$ and 3682 ( $\mathrm{V}_{\text {linked }}$ water $)$, $1590\left(v_{\text {asco }}\right), 1382\left(v_{\mathrm{sco}}\right), 838\left(\mathrm{PF}_{6}\right), 738\left(\mathrm{v}_{\text {imid. deform. }}\right), 553 \mathrm{~cm}^{-1}$ $\left(\mathrm{PF}_{6}\right)$ (strong bands only). 
[36] K. M. Faulkner, S. I. Liochev, I. Fridovich, J. Biol. Chem. 1994, $269,23471-23476$

[37] D. P. Riley, S. L. Henke, P. J. Lennon, R. H. Weiss, W. L. Neumann, W. J. J. Rivers, K. W. Aston, K. R. Sample, H. Rahman, C.-S. Ling, J.-J. Shieh, D. H. Busch, W. Szulbinski, Inorg. Chem. 1996, 119, 5213-5231.

[38] A. Deroche, 1. Morgenstern-Badarau, M. Cesario, J. Guilhem, B. Keita, L. Nadjo, C. Houée-Levin, J. Am. Chem. Soc. 1996, $118,4567-4573$.

[39] D. P. Riley, P. J, Lennon, W, L. Neumann, R. H. Weiss, J. Am. Chem. Soc. 1997, 119, 6522-6528.

${ }^{[40]}$ B. J. Day, I. Fridovich, J. D. Crapo, Arch. Biochem. Biophys. $1997,347,256-262$

[41] 1. Batinic-Haberle, S. I. Liochev, I. Spasojevic, I. Fridovich, Arch. Biochem. Biophys, 1997, 343, 225-233.

${ }^{[42]}$ I. Batinic-Haberle, L. Benov, I. Spasojevic, I. Fridovich, J. Biol Chem. 1998, 273, 24521-24528.

[43] R. Kachadourian, I. Batinic-Haberle, I. Fridovich, Inorg. Chem. 1999, 38, 391-396.

[44] D. P. Riley, S. L. Henke, P. J. Lennon, K. Aston, Inorg. Chem. 1999, 38, 1908-1917.

(45) D. Salvemini, Z.-Q. Wang, J. L. Zweier, A. Samouilov, H. Macarthur, T. P. Misko, M. G. Currie, S. Cuzzocrea, J. A. Sikorski, D. P. Riley, Science 1999, 286, 304-305.

146) A. Carlioz, M. L. Ludwig, W. C. Stallings, J. A. Fee, H. M. Steinman, D. Touati, J. Biol. Chem, 1988, 263, 1555-1562.

${ }^{[47]}$ M. L. Ludwig, A. L. Metzger, K. A. Pattridge, W. C. Stallings, J. Mol. Biol. 1991, 219, 335-358.

(48) G. O. E. Borgstahl, H. E. Parge, M. J. Hickey, W. F. Beyer, R A. Hallewell, J. A. Tainer, Cell 1992, 71, 107-118.

${ }^{149]}$ M. S. Lah, M. M. Dixon, K. A. Pattridge, W. C. Stallings, J. A. Fee, M. L. Ludwig, Biochem. 1995, 34, 1646-1660.

[50i] R. A. Edwards, H. M. Baker, M. M. Whittaker, J. W. Whittaker, G. B. Jameson, E. N. Baker, J. Bioinorg. Chem. 1998, 3, $161-171$

[51] C. Policar, F. Lambert, M. Cesario, I. Morgenstern-Badarau. Eut: J. Inorg. Chem. 1999, 2201-2207.

${ }^{[52]}$ K. Nakamoto, Infrared and Raman Spectra of Inorganic and Coordination Compounds, J. Wiley and Sons, New York, 1978.

[53] S. Gou, X. You, K. Yu, J. Lu, Inorg. Chem. 1993, 32, $1883-1887$

${ }^{[54]}$ H. Iikura, T. Nagata, Inorg. Chem. 1998, 37, 4702-4711.

${ }^{[55]}$ D. T. Sawyer, T. S, Calderwood, K. Yamaguchi, C. T. Angelis, Inorg. Chem. 1983, 22, 2577-2583.

${ }^{566}$ D. P. Riley, W. J. Rivers, R. H. Weiss, Anal. Biochem. 1991, 196, 344-349.

${ }^{[57]}$ E. Friedman, W. Low, Phys. Rev 1960, 120, 408-410.

[58] B. Bleaney, R. S, Rubins, Proc. Phys, Soc, 1961, 77, 103-112.

[59] B. Bleaney, R. S. Rubins, Proc. Plys. Soc, 1961, 78, 778.

${ }^{160]}$ Y. Nishida, N. Tanaka, A. Yamazaki, T. Tokii, N. Hashimoto, K. Ide, K. Iwasawa, Inorg. Chem. 1995, 34, 3616-3620.

(61) M. Perrée-Fauvet, A. Gaudemer, J, Bonvoisin, J. J. Girerd, C. Boucly-Goester, P. Boucly, Inorg. Chem. 1989, 28, 3533-3538.

${ }^{162}$ R. H. Weiss, A. G. Flickinger, W. J. Rivers, M. M. Hardy, K. W. Aston, U. S. Ryan, D. P. Riley, J. Biol. Chem. 1993, 268, 23049-23054.

163] Y. Sawada, I. Yamazaki, Biochim. Biophys. Acta 1973, 327, $257-265$

${ }^{164]}$ S. R. Cooper, G, C. Dismukes, M. P. Klein, M. Calvin, J. Am. Chem. Soc: 1978, 100, 7248-7252.
${ }^{165]}$ G. C. Dismukes, J. E. Sheats, J. A. Smegal, J. Am. Chem. Soc. $1987,109,7202-7203$.

${ }^{[66]}$ M. Suzuki, H. Senda, Y. Kobayashi, H. Oshio, A. Uehara, Chem. Lett. 1988, 1763-1766.

${ }^{[67]}$ H. Diril, H.-R. Chang, M. J. Nilges, X. Zhang, J. A. Potenza, H. J. Schugar, S. S. Isied, D. N. Hendrickson, J. Am. Chem. Soc $1989,1 / 1,5102-5114$

${ }^{[68]}$ P. A. Goodson, J. Glerup, D. Hodgson, K. Michelsen, E. Pedersen, Inorg. Chem. 1990, 29, 503-508.

${ }^{169]}$ E. J. Larson, V. L. Pecoraro, Introduction to Manganese Enzymes, in Manganese Redox Enzymes, VCH Publishers, New York, 1992 , p. $1-28$.

[70] A. Haddy, G. S. Waldo, R. H. Sands, J. E. Penner-Hahn, Inorg. Chem. 1994, 33, 2677-2682,

${ }^{171]}$ M. Zheng, S. V. Khangulov, G. C. Dismukes, V. V. Barynin, Inorg. Chem. 1994, 33, 382-387.

172] M. Zheng, G. C. Dismukes, Inorg. Chem. 1996, 35, 3307-3319.

[73] W. Zwyegart, R. Bittl, K. Wieghardt, W. Lubitz, Chem. Phys. Lett. 1996, 261, 272-276.

[74] Y.-M. Frapart, A. Boussac, R. Albach, E. Anxolabéhére-Mallart, M. Delroisse, J.-B. Verlhac, G. Blondin, J-J. Girerd, J. Guilhem, M. Cesario, A. W. Rutherford, D. Lexa, J. Am. Chem. Soc. 1996, 2669-2678

175] C. Policar, M. Knüpling, Y. M. Frapart, S. Un, J. Phys. Chem. $1998,102,10391-10398$.

(76) C. Hureau, G. Blondin, C. Mathonière, unpublished results

177] K. J. Brewer, M. Calvin, R. S. Lumpkin, J. W. Otvos, L. O. Spreer, Inorg. Chem. 1989, 28, 4446-4451.

${ }^{178]}$ D. R. Gamelin, M. L. Kirk, T. L. Stemmler, P. Samudranil, W. H. Armstrong, J. E. Penner-Hahn, E. I. Solomon, I. Am. Chem. Soc. 1994, 116, 2392-2399.

[79] A. E. Martell, R. M. Smith, Critical Stability Constants. Plenum Press, New York, 1975, vol. 2.

${ }^{180 j}$ A. E. Martell, R. M. Smith, Critical Stability Constants, Plenum Press, New York, 1977, vol. 3.

${ }^{1811}$ A. E. Martell, R. M. Smith, Critical Stability Constants, Plenum Press, New York, 1982, vol. 5 .

${ }^{[82]}$ Extra-dry DMSO is no longer available from Acros but similar quality can be purchased from Aldrich.

[83] P. E. Iberson, H. Lund, Acta Chem. Scand, 1966, 20, 2649.

${ }^{[84]}$ Microanalysis is consistent with one water molecule per manganese ion. This discrepancy between microanalysis and X-ray data may stem from the drying of the powder in vacuo prior to microanalysis.

${ }^{[85]}$ Enraf-Nonius, Delft. The Netherlands, 1997

${ }^{[86]}$ Z. Otwinowski, W. Minor, "Macromolecular Crystallography, Part A", in Methods in Enzymology, Academic Press, London, New York, 1997, p. 307-326.

${ }^{[87]}$ G. M. Sheldrick, Acta Crystallogr, Sect. A 1990, 46, 467.

${ }^{[88]}$ G. M. Sheldrick, University of Göttingen, Germany, 1993.

${ }^{189]}$ S. Kim, R. DiCosimo, J. J. San Filippo, Anal. Chem. 1979, $51,679-681$.

${ }^{190]}$ D. T. Sawyer, J. L. Robert, J. Electroanal. Chem. 1966, I2, $90-101$

[91] A. O. Allen, C. J. Hochanadel, J. A. Ghormley, T. W. Davis, J. Phys. Chem. 1952, 56, 575-586.

${ }^{192]}$ M. C. Rodriguez, I. Morgenstern-Badarau, unpublished results. 
Crystal Data for 2: $\mathrm{Mn}_{2} \mathrm{C}_{24} \mathrm{H}_{40} \mathrm{~N}_{10} \mathrm{O}_{8} \cdot 2 \mathrm{PF}_{6} \cdot \mathrm{H}_{2} \mathrm{O}$, $^{[84]} M_{\mathrm{r}}=1014.47$, monoclinic, space group $P 2_{1} / c, a=9.240(4), b=28.978(11), c=$ 15.586(6) A, $\beta=95.49(4)^{\circ}, V=4154.1 \mathrm{~A}^{3}, Z=4, D_{\text {calos }}=$ $1.622 \mathrm{~g} . \mathrm{cm}^{-3}, \lambda=0.71073 \AA \mathrm{A}, T=293(2) \mathrm{K}, \mu\left(\mathrm{Mo}-K_{o}\right)=$ $0.796 \mathrm{~mm}^{-1}, F(000)=2064$. A prismatic crystal of dimensions 0.28 $\times 0.15 \times 0.10 \mathrm{~mm}$ was mounted on an Enraf-Nonius KappaCCD diffractometer. A full sphere of data was collected by $\varphi$ axis rotation with an increment of $1.5^{\circ}$ over $360^{\circ}$ and $170 \mathrm{~s}$ exposure per degree. "Dezingering" was accomplished by measuring each frame twice. The $\theta$ range for data collection was 1.41 to $29.07^{\circ}$. Data were analyzed using Kappa-CCD software. ${ }^{[85]}$ Cell dimensions were refined with HKL Scalepack. ${ }^{[86]}$ Data reduction was performed with Denzo. ${ }^{[86]}$ Of a total of 13461 collected reflections, 7525 were independent $\left(R_{\text {int }}=0.046\right)$ and 4729 unique reflections had $I \geq 2 \sigma(l)$. The structure was solved by direct methods (program SHELXS-86 ${ }^{[87]}$ ) and was refined on $F^{2}$ for all reflections by least-squares methods using SHELXL-93 ${ }^{[881}$ Hydrogen atoms were included in calculated positions by using a riding model and were assigned isotropic thermal parameters 1.2 times that of the atoms to which they were bound. The asymmetric unit consists of one dimeric $\mathrm{Mn}^{\mathrm{II}}$ complex, two $\mathrm{PF}_{6}$ counteranions, and a water solvent molecule. The counteranions are subject to disorder. Two sites could be located on the difference Fourier map for each $\mathrm{PF}_{6}$ anion. Several models for this disorder were tested. The best convergence was obtained with occupancies of 0.8 and 0.2 . Refinement was pursued with restraints. The final conventional $R_{1}$ factor was found to be 0.075 for 4729 data, 84 restraints, and 585 parameters, and 0.13 for all data, $w R_{2}=0.26$ (all data); the largest peak and hole in the final difference map were within +0.5 and $-0.3 \mathrm{eA}^{-3}$. A selection of bond lengths and angles is presented in Table 2. A perspective view of the Mn dimeric complex is shown in Figure 2. The hydrogen-bond network includes both intra- and intermolecular hydrogen bonds in the crystal structure, involving both the water molecules coordinated to the metal center (first coordination sphere), the noncoordinated oxygen atoms of the bis( $\mu$-carboxylato $)$ bridges of the dimeric complex, and the water solvent molecule included in the crystal structure. Structural data have been deposited with the Cambridge Crystallographic Data Centre (CCDC) under the depository number CCDC-150159. Copies of the data can be obtained free of charge on application to the CCDC, 12 Union Road, Cambridge CB2 1EZ, U.K. [Fax: (internat) + 44-1223/336-033; E-mail:deposit@ccdc.cam.ac.uk].

Reactivity in Anhydrous DMSO: Glassware was dried for at least one night at $125^{\circ} \mathrm{C}$ and then cooled under a stream of argon. Solutions were manipulated in a Schlenk apparatus under a flow of argon and were kept under argon pressure. It was checked that superoxide disproportionation was negligible under the experimental conditions used (see below). DMSO solutions were prepared immediately prior to use. Saturated solutions of $\mathrm{KO}_{2}$ in DMSO were obtained by stirring finely ground $\mathrm{KO}_{2}$ in anhydrous DMSO for $1 \mathrm{~h}$. The slurry was centrifuged for $10 \mathrm{~min}$ at $13000 \mathrm{~g}$ and the supernatant, which was slightly yellow, was titrated spectrophotometrically at $250 \mathrm{~nm}\left(\varepsilon=2686 \mathrm{M}^{-1} \mathrm{~cm}^{-1}\right) .^{[89]}$ Concentrations from $5 \mathrm{~mm}$ up to $6.5 \mathrm{~mm}$ were reproducibly obtained. We checked that this concentration was stable by recording UV/Vis spectra over a period of $10 \mathrm{~min}$, in the course of which a decrease of less than $10 \%$ was usually recorded. This centrifugation procedure was compared with filtration and was found to provide solutions with slightly higher concentrations and improved stabilities (less decrease over $10 \mathrm{~min}$ ). For cyclic voltammetry experiments, saturated solutions of $\mathrm{KO}_{2}$ were prepared in $0.1 \mathrm{M} \mathrm{Bu} \mathrm{NPF}_{6}$ in DMSO. The same superoxide concentration was obtained.
EPR Experiments: Several concentrations of the complexes were tested $\left(2 \times 10^{-4} \mathrm{~mol} \cdot \mathrm{dm}^{-3}, 6.5 \times 10^{-4} \mathrm{~mol} \cdot \mathrm{dm}^{-3}\right.$, and $1 \times 10^{-3}$ $\left.\mathrm{mol} \cdot \mathrm{dm}^{-3}\right)$. For each concentration, the experiment was performed in duplicate. Several Eppendorf vials were prepared containing the complex and $0-5$ equiv. of superoxide with a final volume of $1 \mathrm{~mL}$. Similar Eppendorf vials were prepared with superoxide alone (with quantities corresponding to $0.5-2$ equiv.). These tubes were used to check that the superoxide EPR signal was observed under the experimental conditions. The intensity of the $g=2.00$ signal was shown to vary linearly with superoxide concentration and could thus be used to give a rough estimate of the concentration in each experiment. After superoxide had been added, the Eppendorf vial was stirred manually. An aliquot of $100 \mu \mathrm{L}$ was transferred to an EPR tube, immediately frozen in an EtOH/liq. $\mathrm{N}_{2}$ bath, and kept in liq. $\mathrm{N}_{2}$. EPR spectra were then recorded, either at $100 \mathrm{~K}$ or at $8 \mathrm{~K}$. To estimate the conversion of $\mathrm{Mn}^{\prime \prime}$ to $\mathrm{Mn}^{111} \mathrm{Mn}^{1 \mathrm{v}}$, a calibration curve was constructed. The spectra of a fully characterized bis( $\mu$-oxo $) \mathrm{Mn}^{\mathrm{II}} \mathrm{Mn}^{\mathrm{IV}}$ compound, namely $\left[\mathrm{Mn}_{2} \mathrm{O}_{2}\right.$ bispic$\left.(\mathrm{Me})_{2} \mathrm{en}\right]^{3+},{ }^{[76]}$ at concentrations of $0.25 \times 10^{-4} \mathrm{~mol} \cdot \mathrm{dm}^{-3} \cdot 0.5 \times$ $10^{-4} \mathrm{~mol} \cdot \mathrm{dm}^{-3}, 1 \times 10^{-4} \mathrm{~mol} \cdot \mathrm{dm}^{-3}$, and $1.5 \times 10^{-4} \mathrm{~mol} \cdot \mathrm{dm}^{-3}$ in DMSO were recorded. The relative intensity of the six main peaks was plotted against concentration.

UV/Vis Experiments: Several concentrations were tested $\left(1 \times 10^{-4}\right.$ $\left.\mathrm{mol} \cdot \mathrm{dm}^{-3}, 2 \times 10^{-4} \mathrm{~mol} \cdot \mathrm{dm}^{-3}, 6.5 \times 10^{-4} \mathrm{~mol} \cdot \mathrm{dm}^{-3}\right)$. Successive equivalents of superoxide were directly added to the cuvette under magnetic stirring. EPR spectra of the solution from the cuvette were also recorded.

Cyclic Voltammetry Experiments: Cyclic voltammetry experiments were performed at room temperature under a stream of argon either in extra-dry DMSO containing $0.1 \mathrm{M} \mathrm{Bu}_{4} \mathrm{NPF}_{6}$ or in acetonitrile containing $0.1 \mathrm{M} \mathrm{Bu}_{4} \mathrm{NPF}_{6}$. $\mathrm{An} \mathrm{Ag} / \mathrm{AgClO}_{4}$ electrode $\left(\mathrm{AgClO}_{4}\right.$ $10^{-2} \mathrm{M}, \mathrm{Bu}_{4} \mathrm{NPF}_{6} 0.1 \mathrm{M}$ ) in DMSO was used as a reference for DMSO solutions and was separated from the solution by a glass frit. Its potential was measured as $+0.252 \mathrm{~V}$ vs. SCE. Potentials are reported in the text vs. SCE. The working electrode was a platinum disc ( $2 \mathrm{~mm}$ diameter). Concentrations were $5 \times 10^{-4} \mathrm{M}$ and $1 \times 10^{-3} \mathrm{M}$ based on $\mathrm{Mn}^{11}$ content. When dioxygen-saturated electrolyte was required, dioxygen was bubbled through $0.1 \mathrm{M} \mathrm{Bu}_{4} \mathrm{NPF}_{6}$ in DMSO for half an hour. ${ }^{[55,60,90]}$

Xanthine/Xanthine Oxidase-Cytochrome $c$ Assay: Superoxide anion was supplied to the system from the xanthine/xanthine oxidase reaction.

Reliability of the X/XO Test: To check that the tested compounds do not inhibit the production of superoxide by xanthine oxidase. the rate of conversion of xanthine to urate was determined by measuring the increase in absorbance at $290 \mathrm{~nm}$ over a period of $2 \mathrm{~min}$ in the absence and in the presence of the tested compounds. At concentrations higher than the $I C_{50}$ values (which are of the order of 2-5 $\mu \mathrm{M}$, see below), neither MnIPG nor MnBIG was found to inhibit this conversion. We also verified that ferricytochrome $c$ was stable in the presence of both MnIPG and MnBIG. Moreover, it was important to ascertain whether the tested compounds react with $\mathrm{H}_{2} \mathrm{O}_{2}$ under the experimental conditions, as such a pathway could have led to side reactions. ${ }^{[62]}$ Catalase can be added to the cuvette during the $\mathrm{X} / \mathrm{XO}$ assay, ${ }^{[38][62]}$ but this introduces another potential source of cross-reaction and interpretative errors. ${ }^{[51}$ Instead, we probed the $\mathrm{H}_{2} \mathrm{O}_{2}$ reaction with the complexes at a concentration in the range of the $I C_{50}$ under the experimental conditions of the $\mathrm{X} / \mathrm{XO}$ assay. The $\mathrm{H}_{2} \mathrm{O}_{2}$ concentration was found to be stable over a period of $20 \mathrm{~min}$ (see below).

Xanthine to Urate Assay: To measure the rate of conversion of xanthine to urate, xanthine oxidase (XO) $\left(30 \mu \mathrm{L}\right.$ of $\left.0.77 \mathrm{U} \cdot \mathrm{mL}^{-1} \mathrm{XO}\right)$ 
was added to a potassium phosphate buffer solution $(50 \mathrm{~mm}, \mathrm{pH}=$ 7,8 ) containing $150 \mu \mathrm{M}$ of xanthine at $25^{\circ} \mathrm{C}$ to give a final volume of $1.0 \mathrm{~mL}$. Urate production was monitored at $290 \mathrm{~nm}$. No difference in the slope was observed in the presence or absence of the putative SOD mimics.

Reduction of Ferricytochrome $c$ : The activities were measured on the basis of the ferricytochrome $c$ reduction. ${ }^{17.35|| 62 \mid}$ Assays were performed at $25^{\circ} \mathrm{C}$ in $3 \mathrm{~mL}$ of reaction buffer $(50 \mathrm{~mm}$ potassium phosphate buffer, $\mathrm{pH}=7.8$ ) containing $22 \mu \mathrm{M}$ ferricytochrome $c$, $200 \mu \mathrm{M}$ xanthine, and an amount of xanthine oxidase such as to give a rate of $\Delta D_{550 \mathrm{~nm}}=0.025 \mathrm{~min}^{-1}$ (about $0.01 \mathrm{U} \cdot \mathrm{mL}^{-1}$ ) in the absence of any putative SOD mimic. The reduction of ferricytochrome $c$ was monitored at $550 \mathrm{~nm}$. After $2 \mathrm{~min}$, various amounts of the relevant putative SOD mimic were added. Rates were linear for at least $8 \mathrm{~min}$. The rates both in the absence and in the presence of the complex were determined for each concentration of complex added. The $I C_{50}$ value represents the concentration of the putative SOD mimic that induces $50 \%$ inhibition of the reduction of cytochrome $c$. Values were determined as exemplified in Figure 7, where $p_{1}$ is the slope before addition of the putative SOD mimic and $p_{2}$ is the slope after its addition. The percentage inhibition is given by $\% I=\left(p_{1}-p_{2}\right) / p_{1} \cdot 100$. For each $I C_{50}$ determination, $\% I$ was measured for several concentrations in the region of the $I C_{50}$. The $I C_{50}$ value was obtained for $\% I=50 \%$. Additionally, $\left(p_{1}-p_{2}\right) / p_{2}$ was also plotted against the complex concentration and the $I C_{50}$ value was obtained for $\left(p_{1}-p_{2}\right) / p_{2}=1 .^{[63]}$ For tests with EDTA, this chelator was added to provide a final concentration of $3 \mathrm{mM}$ in the cuvette. For tests with BSA, $30 \mu \mathrm{L}$ of BSA $\left(50 \mathrm{mg} \cdot \mathrm{mL}^{-1}\right)$ was added 4 min after the addition of xanthine oxidase and $2 \mathrm{~min}$ after the addition of the putative SOD mimic.

Reaction of Complexes with $\mathrm{H}_{2} \mathrm{O}_{2}$ under the $\mathrm{X} / \mathrm{XO}$ Assay Conditions: $\mathrm{H}_{2} \mathrm{O}_{2}$ (10 equiv.) was added to a solution of the complex (2 $\left.\times 10^{-6} \mathrm{M}\right)$ in potassium phosphate $(50 \mathrm{~mm}, \mathrm{pH}=7.8)$. The $\mathrm{H}_{2} \mathrm{O}_{2}$ concentration was determined at intervals of $5 \mathrm{~min}$ over half an hour by oxidation of iodide using the Ghormley method (colorimetric titration). ${ }^{[91]}$

\section{Acknowledgments}

We thank Dr. Philippe Maillard and Dr. Elodie Anxolabéhère-Mallart both for technical assistance and for discussions concerning electrochemistry, Prof. $\mathrm{H}$. Toftlund for helpful suggestions, and Dr. J. P. Renault for useful discussions and comments. We also acknowledge Dr. Aurore Gref for lending us a platinum electrode. We would like to thank one of the referees for the suggestion to estimate the conversion of $\mathrm{Mn}^{11}$ species to the $\mathrm{Mn}^{\mathrm{II}} \mathrm{Mn}^{T V}$ compound. We are grateful to Prof. J. J. Girerd's group for kindly providing us with the $\mathrm{Mn}^{11 \mathrm{M}} \mathrm{Mn}^{1 \mathrm{~V}}$ compound used as a concentration standard, in particular we would like to thank C. Hureau, Dr. G. Blondin. and Dr. P. Dorlet. We acknowledge the European Community for financial support (TMR contract FMRX-CT980174).

II] W. R. Jakoby, D. M. Ziegler, J. Biol. Chem. 1990, 265, 20715-20718.

${ }^{[2]}$ B. Halliwell, J. M. C. Gutteridge, "Oxygen Radicals in Biological Systems" in Methods in Enzymology (Eds.: L. Packler. A. N. Glazer), Academic Press, New York, 1990, 1-85.

[3] D. Mansuy, P. Battioni, "Dioxygen Activation at Heme Centers in Enzymes and Synthetic Analogs" in Bioinorganic Catalysis, Marcel Dekker. New York. 1995, p. 395-423.

[4] I. Fridovich, Ann. Rev. Biochem. 1995, 64, 97-112.

[5] D. P. Riley, Chem. Rev. 1999, 99, 2573-2587.

[6] Abbreviations: SOD: superoxide dismutase: IPG: $N-[$ [1-methyl- imidazol-2-yl)methyi]- $N$-(2-pyridylmethyl)glycinate; BIG: $N, N$ bis[(1-methylimidazol-2-yl)methyl]glycinate; DMSO: dimethyl sulfoxide; EPR: electron paramagnetic resonance; $\mathrm{CV}$ : cyclic voltammetry; SCE; saturated calomel electrode; EC process: Electrochemical-Chemical process; $\mathrm{X} / \mathrm{XO}$ : xanthine/xanthine oxidase; EDTA: ethylenediaminetetraacetate; BSA: bovine serum albumine; TPAA: tris $\{2-[N-(2-$ pyridylmethyl $)$ amino]ethyl ;amine; $I C_{50}: 50 \%$ inhibition concentration; LMCT: ligand $\rightarrow$ metal charge transfer.

[7] J. M. McCord, I. Fridovich, J. Biol. Chem. 1969, 244. 6049-6055.

${ }^{[8]}$ S. J. Lippard, J. M. Berg, Principles of Bioinorganic Chemistry, University Science Books, Mill Valley, California, 1994.

${ }^{[9]}$ I. Bertini, S. J. Gray, S. J. Lippard, J. S. Valentine, Bioinorganic Chemistry, University Science Books, Mill Valley, California. 1994.

${ }^{[10]}$ H.-D. Youn, E.-J. Kim, J--H. Roe, Y. C, Hah, S.-O. Kang, Biochem. J. 1996, 318, 889-896.

[ii] I. Fridovich, J. Exp. Biol. 1998, 201, 1203.

${ }^{1} 121$ P. K. Coughlin, A. E. Martin, J. C. Dewan, E.-I. Watanabe, J. E. Bulkowski, J.-M. Lehn, S. J. Lippard, Inorg. Chem. 1984. 23. 1004-1009.

${ }^{[13]}$ E. Kimura, T. Koike, Y. Shimizu, M. Kodama, Inorg. Chem. $1986,25,2242-2246$.

${ }^{[14]}$ J.-L. Pierre, P. Chautemps, S. Refaif, C. Beguin, A. El Marzuki. G. Serratrice, E. Saint-Aman, P. Rey, J. Am. Chem. Soc. 1995. 117, 1965-1973.

(15l J. Casanova, G. Alzuet, S. Ferrer, J. LaTorre, J. A. Ramirez, J. Borras, Inorg. Chim. Acta 2000, 304, 170-177.

${ }^{[16]}$ H. Ohtsu, Y. Shimazaki, A. Odani, O. Yamauchi, W. Mori, S. Itoh, S, Fukuzumi, J. Am. Chem. Soc. 2000, 122, 5733-5741.

[17] L. Iuliano, J. Z. Pedersen. A. Ghiselli. D. Pratico, G. Rotilio, F. Violi, Arch. Biochem. Biophys. 1992, 293, 153-157.

${ }^{[18]}$ W. S. Szulbinski, P. R. Warburton, D. H. Busch, Inorg. Chem. $1993,32,5368-5376$.

${ }^{[19]}$ I. Morgenstern-Badarau, F. Lambert, A. Deroche, M. Cesario, J. Guilhem, B. Keita, L. Nadjo, Inorg. Chim. Acta 1998. $275-276,234-241$.

${ }^{[20]}$ T. Nagano, T. Hirano, M. Hirobe. J. Biol. Chem. 1989, 264, $9243-9249$

[21] M. C. Rodriguez, I. Morgenstern-Badarau, M. Cesario, J. Guilhem, B. Keita, L. Nadjo, Inorg. Chem. 1996, 35, 7804-7810.

${ }^{122]}$ M. C. Rodriguez, F. Lambert, M. Cesario, I. Morgenstern-Badarau, Inorg. Chem. 1997, 36, 3525-3531.

${ }^{[23]}$ I. Batinic-Haberle, I. Spasojevic, P. Hambright, L. Benov, A. L. Crumbliss, I. Fridovich, Inorg. Chem. 1999, 38, 4011-4022.

${ }^{[24]}$ Y. Nishida, I. Watanabe, K. Unoura, Chem. Lett. 1991, $1517-1520$

${ }^{125]}$ D. L. Zhang, D. H. Busch, P. L. Lennon, R. H. Weiss, W. L. Neumann, D. P. Riley, Inorg. Chem. 1998, 37, 956-963.

[26] J. K. Howie, D. T. Sawyer, J. Am. Chem. Soc 1976, 98. 6698-6700.

[27] J. S. Valentine, A. E. Quinn, Inorg. Chem. 1976, 15. 1997-1999.

${ }^{128]}$ J. Stein, J. P. Fackler, G. J. McClune, J. A. Fee, L. T, Chan, Inorg. Chem. 1979, 18, 3511-3518.

${ }^{129]}$ W. H. Koppenol, F. Levine, T. L. Hatmaker, J. Epp, J. D. Rush, Arch. Biochem. Biophys. 1986, 251, 594-599.

${ }^{[30]}$ K. S. Yamaguchi, L. Spencer, D. T. Sawyer, FEBS Lell. 1986. 197, 249-252.

[31] W. F. Beyer, I. Fridovich, Arch. Biochem. Biophys, 1989, 271, 149-156.

$132]$ J. D. Rush, Z. Maskos, W. H. Koppenol, Arch. Biochem. Biophys: 1991, 289, 97-102.

${ }^{133]}$ N. Kitajima, M. Osawa, N. Tamura, Y. Moro-Oka, T. Hirano, M. Hirobe, T. Nagano, Inorg. Chem. 1993, 32, 1879-1880.

${ }^{[34]}$ D. P, Riley, R. H. Weiss, J. Am. Chem. Soc: 1994, 116. 387-388.

${ }^{135]}$ K. M. Faulkner, R. D. Stevens, I. Fridovich, Arch. Biochem. Biophys. 1994, 310, 341-346. 